Article

\title{
Characterization and Life Cycle Exergo-Environmental Analysis of Wood Pellet Biofuel Produced in Khyber Pakhtunkhwa, Pakistan
}

\author{
Ahmad Rashedi ${ }^{1}$, Irfan Ullah Muhammadi ${ }^{2}$ (D), Rana Hadi ${ }^{3}$, Syeda Ghufrana Nadeem ${ }^{4}$, Nasreen Khan ${ }^{3}$, \\ Farzana Ibrahim ${ }^{3}$, Mohamad Zaki Hassan ${ }^{5}{ }^{(\mathbb{C}}$, Taslima Khanam ${ }^{1}$, Byongug Jeong ${ }^{6}\left(\mathbb{D}\right.$ and Majid Hussain ${ }^{2, *}$
}

\section{check for}

updates

Citation: Rashedi, A.; Muhammadi, I.U.; Hadi, R.; Nadeem, S.G.; Khan, N.; Ibrahim, F.; Hassan, M.Z.; Khanam, T.; Jeong, B.; Hussain, M. Characterization and Life Cycle Exergo-Environmental Analysis of Wood Pellet Biofuel Produced in Khyber Pakhtunkhwa, Pakistan. Sustainability 2022, 14, 2082. https://doi.org/10.3390/su14042082 Academic Editor: Algirdas Jasinskas

Received: 26 December 2021 Accepted: 7 February 2022

Published: 11 February 2022

Publisher's Note: MDPI stays neutral with regard to jurisdictional claims in published maps and institutional affiliations.

Copyright: (C) 2022 by the authors. Licensee MDPI, Basel, Switzerland. This article is an open access article distributed under the terms and conditions of the Creative Commons Attribution (CC BY) license (https:// creativecommons.org/licenses/by/ $4.0 /)$.
1 College of Engineering, IT and Environment, Charles Darwin University, Ellengowan Drive, Casuarina, NT 0810, Australia; mabrur.rashedi@cdu.edu.au (A.R.); taslima.khanam@cdu.edu.au (T.K.)

2 Department of Forestry and Wildlife Management, University of Haripur, Haripur 22620, Khyber Pakhtunkhwa, Pakistan; irfanmehsud10@gmail.com

3 Department of Zoology, Jinnah University for Women, Nazimabad, Karachi 74600, Sindh, Pakistan; dr.ranahadi@juw.edu.pk (R.H.); dr.nasreenkhan@juw.edu.pk (N.K.); dr.farzanaibrahim@juw.edu.pk (F.I.)

4 Department of Microbiology, Jinnah University for Women, Nazimabad, Karachi 74600, Sindh, Pakistan; s.ghufrana@juw.edu.pk

5 Razak Faculty of Technology and Informatics, Level 7 Menara Razak, Universiti Teknologi Malaysia, Jalan Sultan Yahya Petra, Kuala Lumpur 54100, Malaysia; mzaki.kl@utm.my

6 Department of Naval Architecture, Ocean and Marine Engineering, University of Strathclyde, 100 Montrose Street, Glasgow G4 0LZ, UK; byongug.jeong@strath.ac.uk

* Correspondence: majid@uoh.edu.pk; Tel.: +92-308-8144348

\begin{abstract}
Major objectives of this study were to produce low-emitting wood pellet biofuel from selected agro-forest tree species, i.e., Kikar (Acacia nilotica), Oak (Quercus semicarpifolia), and Mesquite (Prosopis juliflora), grown in the southern part of the Khyber Pakhtunkhwa (KP) province of Pakistan using indigenously developed technology (pelletizer machine). Primary raw material, such as sawdust of the selected agro-forest tree species, was obtained from sawmills located in southern part of KP. Life cycle inventory (LCI) was sourced for entire production chain of the wood pellet biofuel by measuring quantities of various inputs consumed and output produced. In addition, the wood pellets were characterized to examine diameter, length, moisture content, ash content, bulk density, high heating value (HHV), low heating value (LHV), as well as nitrogen and sulphur contents. A comprehensive life cycle assessment was performed for wood pellet biofuel production chain using SimaPro v9.1 software. A functional unit of one (01) kilogram $(\mathrm{kg})$ wood pellet biofuel was applied following a gate-to-gate approach. The results of the present study were in accordance with the recommended Italian standard CTI-R 04/5 except for pellet bulk density and nitrogen content. The bulk density for all wood pellets, manufactured from the saw dust of three different agro-forest tree species, were lower than the recommended Italian standard, while for nitrogen content, the results were higher than the recommended Italian standard. Among the environmental impacts, Kikar (Acacia nilotica) wood pellets were the major contributor to fossil fuel depletion, followed by ecotoxicity, mineral depletion and acidification/eutrophication. This was primarily due to lubricating oil and urea-formaldehyde (UF) resin used as inputs in the wood pellets biofuel manufacture. Likewise, human health and ecosystem quality was also affected by lubricating oil, UF resin, and saw dust, respectively. In cumulative exergy demand of $1 \mathrm{~kg}$ wood pellets biofuel, the highest impact was from Kikar wood pellets for non-renewable fossils, mainly due to lubricating oil used. Difference in environmental impacts, damage assessment, and exergy were examined in three different scenarios for major hotspot inputs by reducing $20 \%$ lubricating oil in case 1,20\% UF resin in case 2, and without usage of UF resin in case 3, while marked reduction was observed in ecotoxicity, fossil fuel, and mineral depletion, as well as acidification/eutrophication impact category. Moreover, a pronounced reduction was also noted in the non-renewable fossil fuel category of cumulative exergy demand of one $\mathrm{kg}$ of wood pellets biofuel produced.
\end{abstract}

Keywords: wood pellets; biofuel; environmental impacts; characterization; exergy; Pakistan 


\section{Introduction}

The demand for fossil fuel resources is a vital problem for future generations [1]. Increase in population results in a rise of the universal atmospheric pollution, due to the emissions from the consumption of fossil fuels [2]. It is projected that 80-85 percent of the world's energy usage is attained directly from fossil fuels [1]. Many countries have a high use of fossil fuels and a low share of renewable energy. Sweden and Iceland, which had little fossil fuel usage and a remarkable proportion of renewables, as well as Norway, which had high shares for both variables, were exceptions [3]. As the primary source of energy for most nations, the use of fossil fuels has resulted in many negative environmental effects, such as air pollution and global warming. Air pollution leads to many health issues, leading to negative social and economic results [4].

Furthermore, fossil fuels will eventually be depleted because they are limited in supply [5]. It is estimated that only about 14 percent of oil-proven reserves, 72 percent of coal-proven reserves, and 18 percent of gas-proven reserves will remain by 2050 . Given the small reserves of fossil fuels, they would easily vanish if they need to use them [4]. Therefore, it is important to aim at reducing the rate of energy consumption and the use of fossil fuels, while also reducing the environmental impact associated with use of petrochemicals [5]. Reducing greenhouse gas emissions in this area will be demanding, albeit urgent, to achieve the goals. Due to the long-term use of petrochemicals, biomass was used as a secondary energy source for decades and has a negligible contribution to the production of primary energy [6]. In order to produce electricity and domestic heating, biomass is used for modern energy. It is used in countries such as Denmark, Sweden, and Finland [7]. Biomass is one of the renewable energy sources with tremendous growth potential in the coming years, and it is considered one of the key choices [8]. Biomass is consumed for heating, electricity generation, cooking, and fuels for transport, thus having environmental benefits [9]. As biomass grows by photosynthesis reactions, biomass matter can be considered to be neutral with respect to $\mathrm{CO}_{2}$ emissions [10,11]. Due to the photosynthetic nature of wood, it has low levels of nitrogen and sulphur, producing low $\mathrm{NO}_{\mathrm{x}}$ and $\mathrm{SO}_{2}$ emissions [12]. The low amounts of particulate matter, $\mathrm{C}_{\mathrm{x}} \mathrm{H}_{\mathrm{y}}$, and $\mathrm{CO}$, helps to prevent the photochemistry of the atmosphere from being affected [13]. Biomass and biological wastes are an independent resource of power, partly avoiding reliance on international energy sources, enhancing the trade balance of a nation and economic sustainability [14]. Wood processing units produce a large quantity of waste that has no additional use, making biomass commercially competitive with fossil fuels as an energy source [6]. Socially, the production of biomass and energy crops promotes job growth, prevents rural depopulation, and promotes local agriculture and forestry. The effect on food production and forests can be reduced in this way [15].

In the near future, pellets manufacturing industry will be one of the fastest growing sectors, as compared to other types of bioenergy resources [16]. More than 800 factories produced about 2 million metric tons (Mt) in 2000 to some 55.7 million metric tons of wood pellets globally in 2018 [17]. In the past ten years, the annual output of biomass pellet fuel has risen by $20 \%$ [18], mainly due to increase in demand for bioenergy resources [19]. Industrial Wood Pellet market is projected to grow from USD 4.33 billion in 2020 to USD 7.69 billion in 2027 at a CAGR of $8.56 \%$ in the $2020-2027$ period. The wood pellet market was valued at US $\$ 9630.99$ million in 2020 and is projected to reach US $\$ 23,892.77$ million by 2028; it is expected to grow at a current annual growth rate (CAGR) of $12.1 \%$ from 2021 to 2028 [19]. The main manufacturers of the biomass pellets are the European Union (49\%), the United States (22\%), Russia (3\%), Canada (10\%), and Vietnam (5\%). In Europe, the European union's 2020 policy for renewable energy and the reduction in greenhouse gas (GHG) emissions are one of the foremost driving forces for the large consumption of wood pellets [20]. The export and production of wood pellets from the southeast of the USA has doubled since 2011 [21,22] the area has become one of the main global suppliers of wood pellets to the European union [23], largely due to EU demand [24]. Wood Pellets (WP) is a renewable energy product that has gained popularity all over the world as a biofuel [25]. 
In addition, wood pellets can be acquired from various kinds of raw materials, such as biomass residues in agricultural or industrial processes, forestry thinning, and specialized crops [26]. In Pakistan, mostly, forest trees are harvested for firewood use, which leads to massive deforestation and ecosystem degradation. About 75\% of the households have used round wood as a principal fuel for cooking, $14 \%$ for water heating, and $11 \%$ for room heating in Pakistan. Wood consumption, in the form of firewood for domestic and industrial energy purpose, is going to increase with the increase in population and industrialization in Pakistan. Therefore, it is a dire need to develop low-emitting, sustainable, cost effective, eco-efficient, and energy-rich pellet biofuel in Pakistan to decrease the environmental and economic burdens on forest resources degradation in Pakistan. In Pakistan, no such study had been conducted on wood pellets biomass until/since now. The fossil fuel resources in Pakistan are extremely costly, expensive, and they have negative impacts on our air, water, and soil, causing ozone layer depletion, having global warming potential, eutrophication, and causing of climate change. Thus, it is a dire need to use alternative biomass wood pellets by replacing fossil fuels. Therefore, the objectives of this study were to produce low-emitting wood pellet biofuel prototypes from selected agro-forest trees species (Acacia nilotica, Quercus semicarpifolia, and Prosopis juliflora) of the southern Khyber Pakhtunkhwa province of Pakistan using indigenously developed technology, i.e., pelletizer machine. Similarly, characterization was performed to assess properties of the developed wood pellets biofuel. In addition, scenario analysis was also performed for the identification of clean and green options using the life cycle assessment approach.

\section{Materials and Methods}

\subsection{Study Area}

Khyber Pakhtunkhwa Province (KP) is located between $34^{\circ} 1^{\prime} 33.3012^{\prime \prime}$ north longitude and $71^{\circ} 33^{\prime} 36.4860^{\prime \prime}$ east latitude, with an area of 128,961 square kilometers. The weather situations in mountainous and lowland areas are different. The mean annual rainfall is between 600 and $1450 \mathrm{~mm}$. Therefore, huge changes in regional hydrological conditions, altitude, and climatic factors have created a variety of biodiversity (both flora and fauna) in different places of this province [27]. The research was conducted in Dera Ismail Khan (D.I. Khan) district and South Waziristan tribal district in the southern part of KP, Pakistan [28].

\subsection{Goal and Scope Definition}

The aim of this study was to produce, characterize and then conduct a comprehensive LCA to find the environmental hotspot throughout the manufacturing process. Furthermore, this work suggests some environmental improvement potentials by considering different scenarios for required energy of the plant [29-31]. This can be broadly defined as 'compare the environmental impacts of the wood pellets bioenergy chain and identified which component processes contribute most to the overall impact score in each case' [29]. Functional unit was $1 \mathrm{~kg}$ wood pellets production from Mesquite, Kikar, and Oak saw dust. It is a measure of the function of wood pellets, and it provides a reference to which the inputs and outputs can be related or referred. The study was gate to gate life cycle assessment. System boundary describes which activity should be included or excluded.

\subsubsection{Data Collection}

The present study was conducted on wood pellets biofuel manufactured through a pelletizer machine, which was developed indigenously by local electrical engineer in Gujjar Ghari market, Mardan city, Pakistan. The indigenously developed pelletizer machine is comprised of ring die with two roller pulleys, which are connected with a 02-horsepower electric motor through a belt to compress and densify the sawdust mixture into wood pellets biofuel, with a size around $8 \mathrm{~mm}$ dimeter and $45 \mathrm{~mm}$ length, as can be seen in (Scheme 1). The underlying working principle of this pelletizer machine is that sawdust mixture is added through the hopper to the pelletization chamber where pellet mill die and rollers are installed. In the pelletization chamber, the rollers compressed the raw 
material in the die holes under high pressure (2-3 pa) and transformed it into cylindrical compact pellets biofuel. The manufactured pellets are poured down through the outlet of the pelletizer machine into the cooling trays. The pellets are then cooled and dried for around 1-2 $\mathrm{h}$ in open environment, and after proper drying, it is suitable for burning in stoves at household level and kilns and furnaces at industrial level.

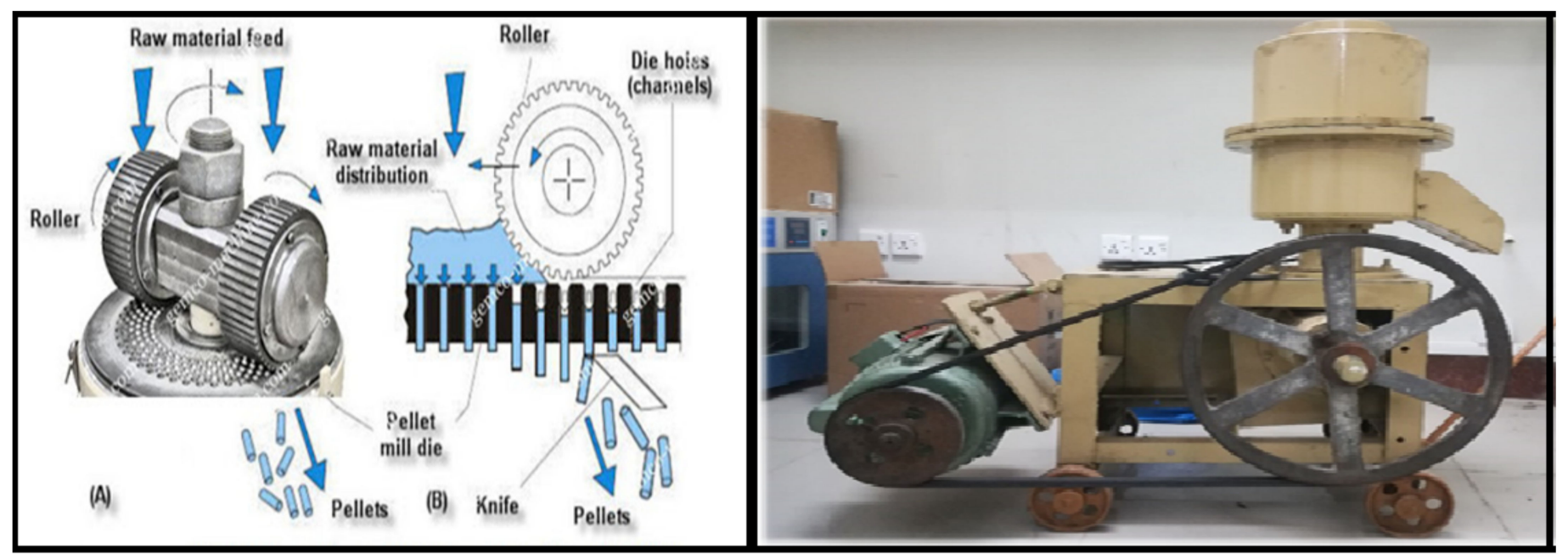

Scheme 1. Diagram of indigenously developed pelletizer machine in KP, Pakistan.

The primary data about sawdust and tree species were collected for wood pellets manufacturing in the study area by visiting different sites such as wood sellers, carpenters' shops, and saw mills. The saw dust was collected and brought to the University of Haripur for pellets production. Saw dust of three hardwood species were selected; Acacia nilotica (Kikar), Quercus semicarpifolia (Oak) and Prosopis juliflora (Mesquite). Life cycle assessment (LCA) was done for wood pellets. LCA is the compilation and evaluation of inputs, outputs, and associated environmental impacts and burdens caused by a system through its different stages of life cycle [32]. LCA studies the potential environmental impacts throughout the products or system's life from raw material acquisition through production, use, and disposal [33]. LCA is the holistic tool for finding environmental, economic, and social performance of a product. There are four main stages in the LCA process: (i) goal and scope definition, (ii) life cycle inventory (LCI), (iii) impact and improvement assessment, and (iv) interpretation [34].

\subsection{Life Cycle Inventory}

LCI analysis involves data collection and calculation procedures to quantify relevant inputs and outputs of a product system. The calculation procedures involve obtaining relevant data for each inventory item, which, together, are compiled to produce the LCI for the functional unit [34], as can be seen in Table 1. The comprehensive LCI data were obtained from the inputs used in pellets production. Inputs and outputs of materials and energy for each process were quantified. Data availability is one of the critical issues on LCA, so very often, practitioners have to use proxy data. The main problem with the proxies is that results will have huge uncertainty, and probability will not be representative. The data should quantify the input and output of the product or services, and should be represented well and completely referenced [35]. 
Table 1. LCI for wood pellets biofuel, manufactured from different tree species.

\begin{tabular}{ccccc}
\hline Inputs & Unit & Mesquite Tree & Kikar Tree & Oak Tree \\
\hline Saw dust use & gram $(\mathrm{g})$ & 635 & 721 & 560 \\
Bio-binder & $\mathrm{g}$ & 136 & 225 & 165 \\
Glue (UF resin) use & $\mathrm{g}$ & 127 & 180 & 119 \\
Water use & Litre $(\mathrm{L})$ & 0.470 & 0.555 & 0.508 \\
Lubricating oil use & $\mathrm{g}$ & 133 & 140 & 166 \\
Electricity consumed & (kilo-Watt-hour) kWh & 0.0046 & 0.0043 & 0.005 \\
\hline & Output & & & \\
\hline Wood pellet produced & Kilogram $(\mathrm{kg})$ & 1 & 1 & 1 \\
\hline
\end{tabular}

\subsection{Life Cycle Impact Assessment}

LCIA is when data or information is transformed into environmental impacts. The environmental impacts of the wood pellets were evaluated using Eco-indicator 99 (E) V2.10 baseline methodology, which is applied for analysis of environmental impacts in a number of different impact categories. In the life cycle impact assessment (LCIA) stage, an assessment is made of the potential human, ecological, and depletion effects of energy, water, and material usage, as well as the environmental releases identified in the inventory. The impact assessment is where the potential effects on the chosen environmental issues are assessed [36].

\subsection{Interpretation}

The data is interpreted and illustrated in the last phase. Interpretation is the final stage of the LCA, but it is crucial in assessing the study's accuracy, uncertainty, limitations, and whether the goal and scope is achieved.

\subsection{Characterization of Wood Pellets Biofuel}

Afterwards, the manufactured pellets were characterized by physical process. Characterization was performed on an experimental basis; the process was repeated, and the average value was taken.

\subsubsection{Moisture}

The moisture test was performed by using a laboratory oven and a precision balance through standard (ASTM D1762). The moisture was also determined through moisture tester. The moisture of the saw dust was within the limit, as mentioned in standards below $12 \%$ [37]. The moisture percentage was calculated through the following Equation (1);

$$
\text { Moisture, } \%=[A-B / A] \times 100
$$

where $\boldsymbol{A}=$ Air dried sample, $\boldsymbol{B}=$ Oven dried sample at $105 \pm 1{ }^{\circ} \mathrm{C}$.

\subsubsection{Dimensions}

The pellets were cylindrical in shape. In order to determine the dimensions, the average size (length) and diameter were determined by randomly selecting 15 pellets and measured with Vernier caliper and scale. Diameter was same for all pellets.

\subsubsection{Bulk Density}

Bulk density was determined by oven dry weight of the sample divided by the volume of the sample, as shown in Equation (2). Volume of sample pellet was measured by caliper and scale. The length was taken as average, and diameter was uniform for all pellets because of same die ring.

$$
\rho=w^{o} / v
$$

$\rho=$ Bulk Density $\left(\mathrm{g} / \mathrm{cm}^{3}\right), \boldsymbol{w}^{o}=$ Oven dry weight, $\boldsymbol{v}=$ volume of pellet. 


\subsubsection{Ash Content}

For the estimation of ash content, the empty porcelain crucibles were placed in an oven at $105 \pm 2{ }^{\circ} \mathrm{C}$ for a period of $45 \mathrm{~min}$. The crucibles were placed in a desiccator for cooling for about $45 \mathrm{~min}$. After that, the oven dry samples were placed in porcelain crucible for a period of about $25 \mathrm{~min}$ at a temperature of $575 \pm 5{ }^{\circ} \mathrm{C}$ (TAPPI T211 om-85).

\subsubsection{Heating Values}

High heating value was obtained through Dulong's formula [38], as shown in Equation (3);

$$
H H V=4.18 \times(78.4 \times C+241.3 \times H+22.1 \times S)
$$

Whereas, $\boldsymbol{C}=$ Carbon $\%, \boldsymbol{H}=$ Hydrogen $\%, \boldsymbol{S}=$ Sulphur $\%$

While low heating value was obtained through Direct method [36];

$$
L H V=4.18 \times(94.14 \times C-0.5501-52.14 \times H)
$$

\subsubsection{Elemental Analysis}

The final analysis of the elements was carried out in the samples through SEM (Scanning electron microscope JSM-IT100). Major elements, such as Carbon, Sulphur, and Nitrogen, were investigated in the study.

\section{Results and Discussions}

\subsection{Environmental Impacts Assessment of Pellets Biofuel}

Environmental impacts for $1 \mathrm{~kg}$ wood pellets, manufactured from the sawdust of three different species, were evaluated as shown in the Figure 1. Among the environmental impacts, fossil fuel was the major contributor to the environmental impacts with the value of (5.116 MJ surplus), followed by ecotoxicity (1.188 PAF.m ${ }^{2}$ yr (Potential of Affected Fraction of species, in terms of ecotoxicity, this is measured as the percentage of all species present in the environment living under toxic stress)), mineral depletion (0.114 MJ surplus), and acidification/eutrophication potential (0.073 PDF.m ${ }^{2} \mathrm{yr}$ (Potential of Disappeared Fraction of plant species)). The major environmental impacts in fossil fuels and ecotoxicity were caused due to Kikar wood pellets (1.87 MJ surplus, 0.48 PAF.m² ${ }^{2}$ r) followed by Oak wood pellets (1.72 MJ surplus, 0.361 PAF.m ${ }^{2} \mathrm{yr}$ ) and lowest was in Mesquite wood pellets (1.52 MJ surplus, 0.347 PAF.m ${ }^{2}$ yr). Mineral depletion and Acidification/eutrophication potential was highest in Kikar wood pellets, followed by Mesquite and Oak wood pellets, respectively, as shown in the Figure 1 below. Mineral depletion and Acidification/eutrophication, compared to fossil fuel and ecotoxicity, were negligible. Carcinogens and respiratory inorganics were almost the same and negligible. They showed lower environmental impacts.

The highest impact on the environment came from fossil fuels $1.875 \mathrm{MJ}$ surplus used during wood pellets production from Kikar saw dust, as shown in Figure 2. The major hotspot source for fossil fuel depletion was lubricating oil $0.875 \mathrm{MJ}$ surplus followed by UF resin 0.805 MJ surplus, Bio binder 0.165, and saw dust 0.0259 MJ surplus, respectively. The major environmental impacts were caused by wood pellets produced from Mesquite saw dust responsible for fossil fuel 1.526 MJ surplus, and the leading responsible factor for fossil fuel was lubricating oil 0.831 MJ surplus, proceeded by UF resin 0.568 , bio binder 0.099, and saw dust 0.0228 MJ surplus, respectively, as shown in Figure 3. Environmental impacts caused by wood pellets produced from Oak saw dust were shown in Figure 4, which showed that the hotspot source for environmental impacts caused by fossil fuels was $1.715 \mathrm{MJ}$ surplus. The most prominent factors responsible for fossil fuels depletion were lubricating oil, UF resin, and bio-binder with values of $1.03,0.532$, and $0.1212 \mathrm{MJ}$ surplus, respectively. 


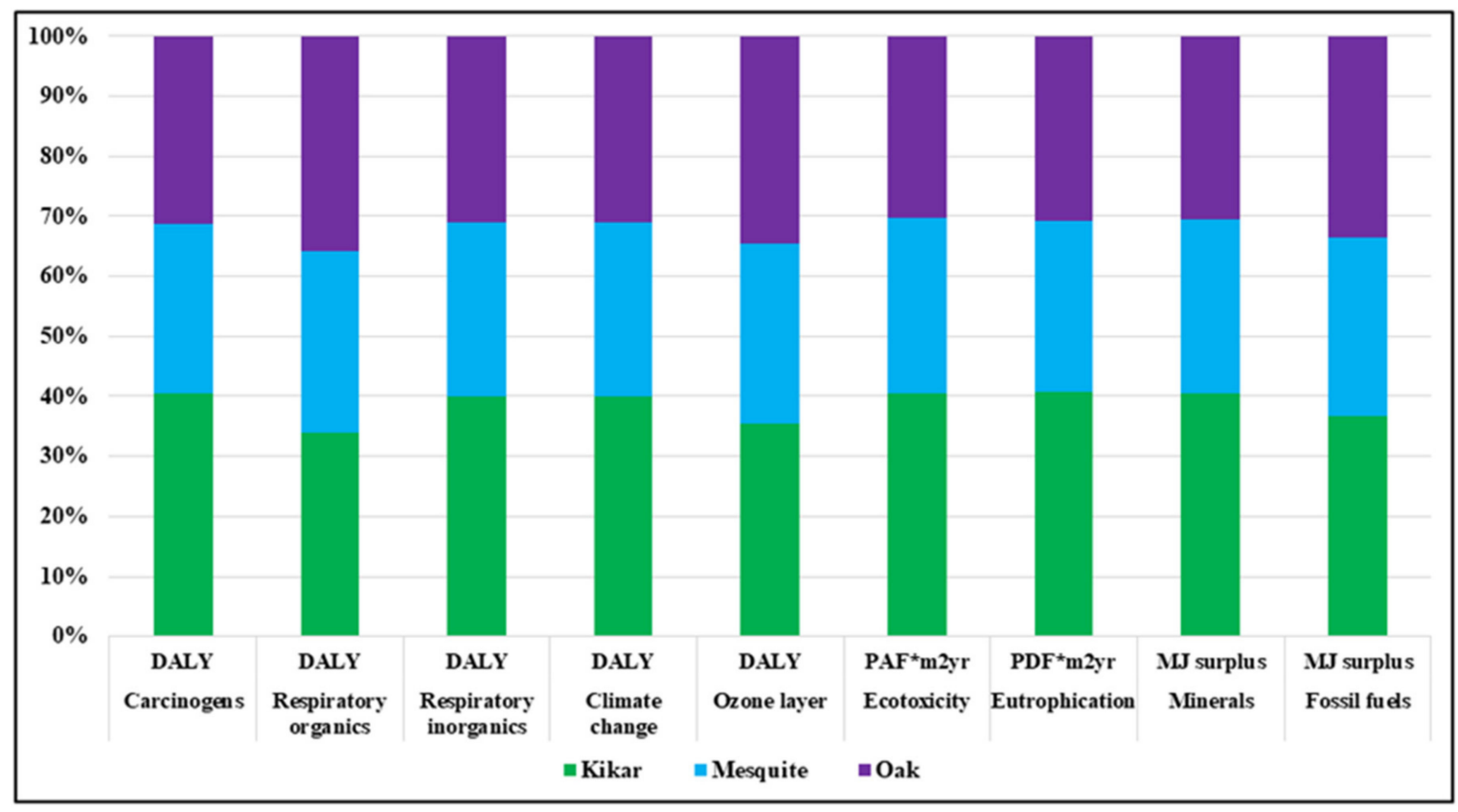

Figure 1. Environmental impacts of wood pellets biofuel from different tree species.

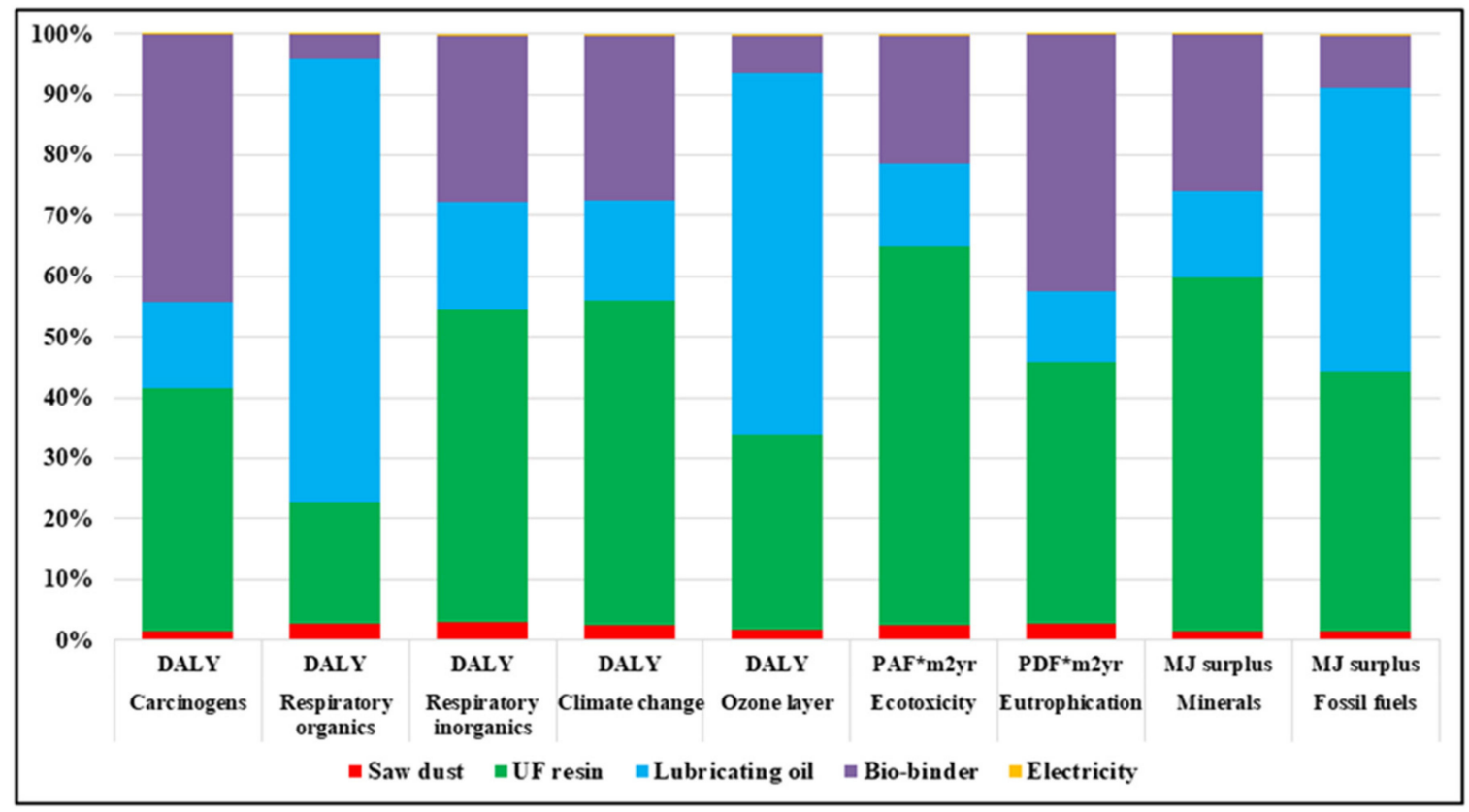

Figure 2. Environmental impacts assessment of wood pellets biofuel from Kikar species. 


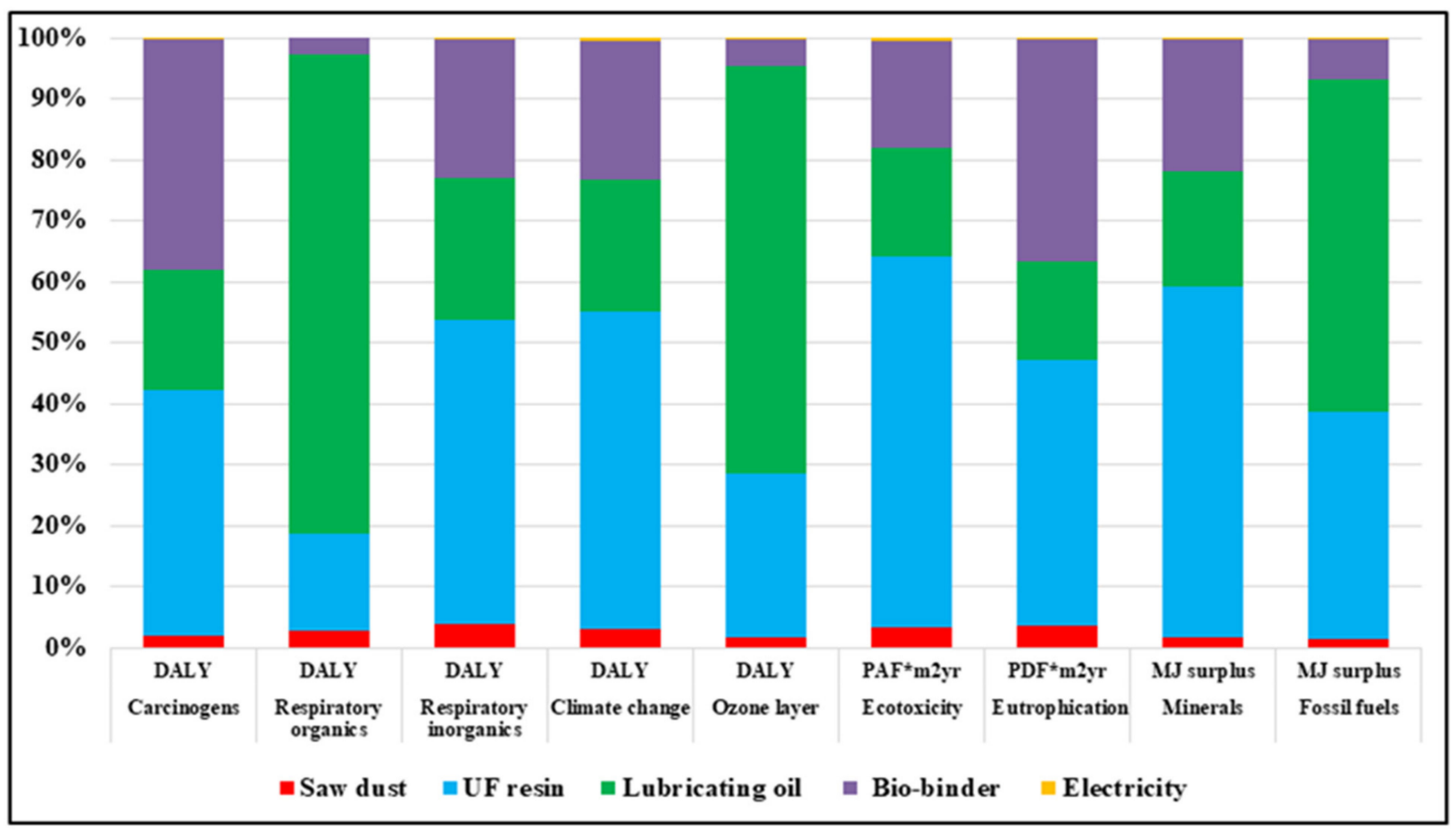

Figure 3. Environmental impacts assessment of wood pellets biofuel from Mesquite species.

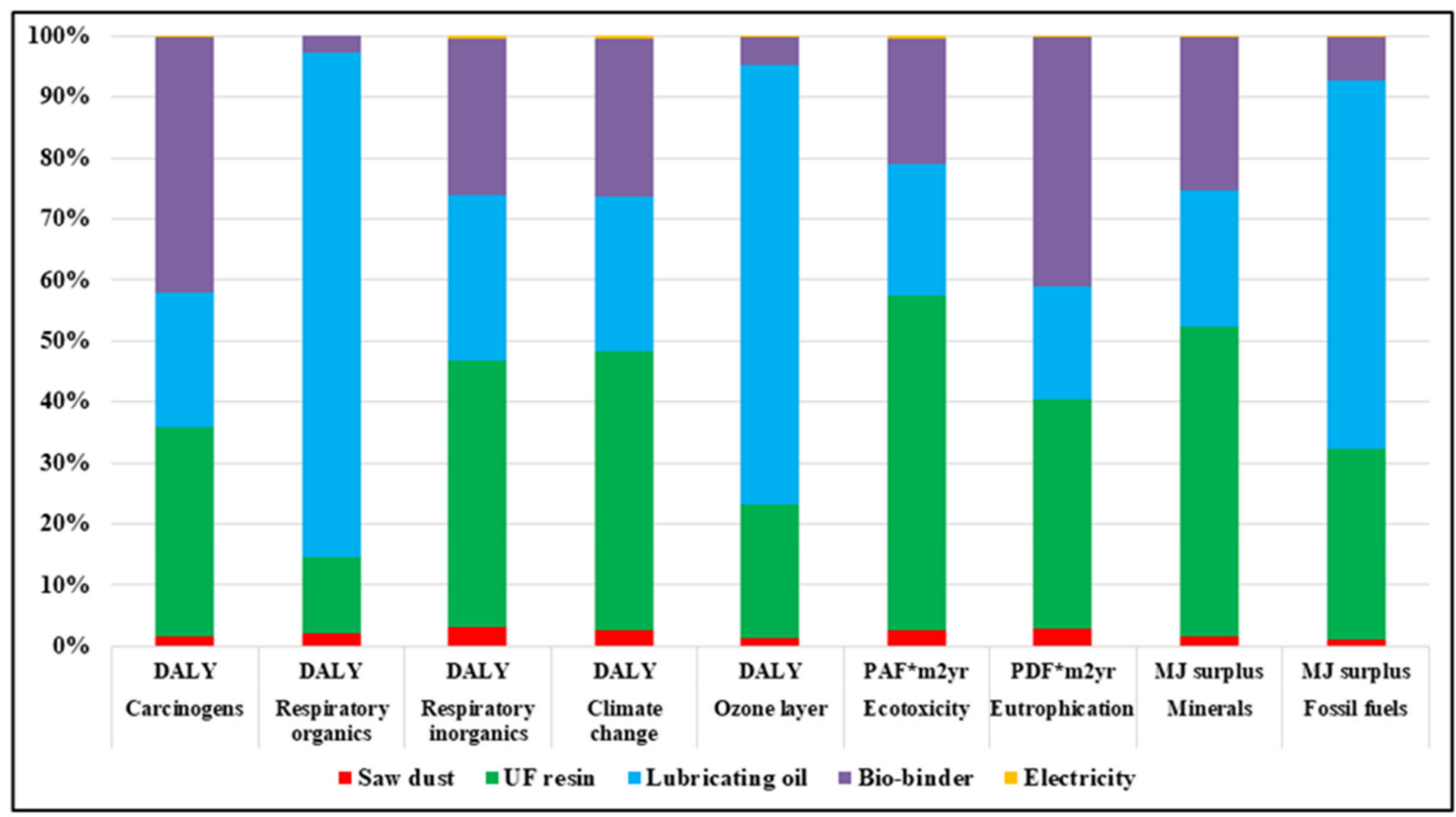

Figure 4. Environmental impacts assessment of wood pellets biofuel from Oak tree species.

The second highest environmental impact category was ecotoxicity caused by wood pellets from Kikar saw dust. The hotspot sources of ecotoxicity were caused due to UF resin, Bio-binder, lubricating oil, and saw dust, as shown in the Figure 2. In Mesquite wood pellets main hotspot sources for ecotoxicity were UF resin, lubricating oil, bio-binder, and saw dust, respectively. The ecotoxicity caused due to wood pellets from Oak saw dust was due to UF resin, lubricating oil, and bio-binder, with values, of $0.198,0.077$ and 0.074 PAF. $\mathrm{m}^{2} \mathrm{yr}$, respectively, while the other two values were minor. 
Mineral depletion in Kikar wood pellets were caused due to UF resin, lubricating oil, and bio-binder, respectively, while the other material such as saw dust, water, and electricity used for production had minor values, as shown in Figure 4. In Mesquite, mineral depletion is due to UF resin and lubricating oil, while the other values were minor in the same way as Kikar. UF resin, Bio-binder, and lubricating oil were the major contributors in mineral depletion from wood pellets produced Oak saw dust. UF resin, bio-binder, and lubricating oil were responsible for acidification potential in wood pellets produced from Kikar saw dust. Here, UF resin and bio-binder had the same impact on acidification potential, while being slightly higher than lubricating oil. The major contributors in acidification/eutrophication were UF resin, Bio-binder, lubricating oil, and saw dust with values of $0.009,0.008,0.003$, and 0.001 PDF.m ${ }^{2} \mathrm{yr}$, respectively, in wood pellets produced from Mesquite saw dust. In Oak wood pellets, the acidification potential was maximum due to bio-binder, lubricating oil, UF resin, lubricating oil, and saw dust, respectively, as shown in the Figure 4 . The other impacts, such as carcinogens, respiratory organics, respiratory inorganics, climate change, and ozone layer were minor, with values of $9.47 \times 10^{-7}$, $2.91 \times 10^{-9}, 1 \times 10^{-6}, 1.93 \times 10^{-7}$, and $2.33 \times 10^{-10}$ DALY, respectively, as compared to the above impacts.

\subsection{Damage Assessment of Pellets Biofuel}

The aim of the analysis is to find out damage assessments used by different raw materials during $1 \mathrm{~kg}$ pellets production. Figure 5 shows the combined damage assessment to human health, ecosystem quality, and resources categorized by wood pellets produced from Mesquite, Kikar, and Oak species. The highest damage was posed to resources depletion with the contribution of (5.35 MJ surplus), followed by ecosystem quality and human health, with values of $\left(0.927\right.$ PAF.m $\left.{ }^{2} \mathrm{yr}\right)$ and $\left(5.35 \times 10^{-6}\right.$ DALY $)$, respectively.

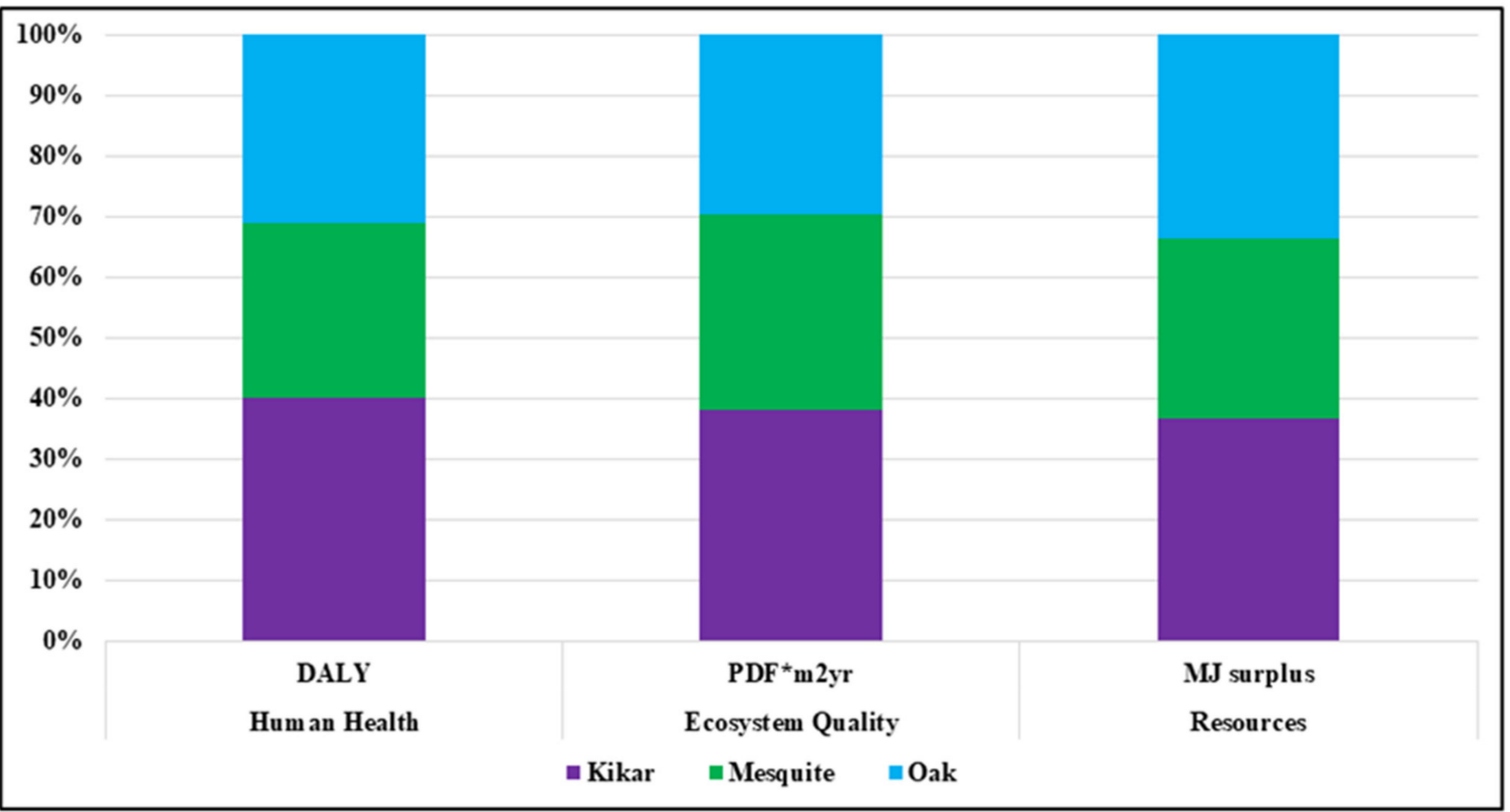

Figure 5. Damage assessment of wood pellets biofuel from different tree species.

Damage to human health was negligible in all the pellets produced from three different species. Damages to ecosystem quality was highest in Kikar wood pellets (0.353 PAF.m² ${ }^{2}$ r) followed by Mesquite wood pellets $\left(3.0 \times 10^{-1}\right.$ PAF.m $\left.{ }^{2} \mathrm{yr}\right)$, while lowest in wood pellets was produced from Oak saw dust $\left(2.75 \times 10^{-1}\right.$ PAF.m $\left.{ }^{2} \mathrm{yr}\right)$. The damage to resources was 
maximum in pellets produced from Kikar saw dust (1.92 MJ surplus) and Oak (1.75 MJ surplus), while lowest was in Mesquite wood pellets (1.6 MJ surplus).

\subsection{Single Score Damage Assessment}

The damage to human health was very low from Kikar saw dust used during pellets production. UF, bio-binder, and lubricating were the hotspot sources for human health damage with values of 45.27, 33.70, and 15.86 (milli-point) $\mathrm{mPt}$, respectively. Human health was also disturbed very little from the saw dust used in the manufacturing of wood pellets but UF resin, Bio-binder, and lubricating oil were the major factors for deterioration of human health from Mesquite tree species. Once again UF resin, bio-binder and lubricating oil were the major factors responsible for damage to human health with values of 29.93, 24.71 , and $15.06 \mathrm{mPt}$, respectively. Wood pellets, manufactured form Oak saw dust as shown in the Figure 6, had minor or negligible damage to human health. The damage of wood pellets, produced from Kikar saw dust, on ecosystem quality was the highest impact from saw dust, lagged by UF resin, bio-binder, lubricating oil, and electricity, respectively. Figure 7 showed the damages created due to wood pellets from Mesquite tree species. Saw dust, UF resin, lubricating oil, and bio-binder had the highest damages to ecosystem quality, respectively, with values of $0.24,0.033,0.014$, and 0.010 PAF.m ${ }^{2}$ yr. Figure 8 showed human health, ecosystem quality, and resources depleted due to pellets manufactured from Oak tree saw dust. Ecosystem quality was depleted mostly due to saw dust, UF resin, lubricating oil, bio-binder, and electricity, respectively. The ecosystem quality depleted due to electricity was negligible. The damage was highest in resources depletion, which was mainly due to burnt lubricating oil and UF resin, while the other factors (bio-binder, saw dust, and electricity) had the least impact as compared to the former. In Mesquite wood pellets, the lubricating oil, UF resin, and bio-binder had impacts on our resources, while saw dust and electricity had very low impacts on resources. In Oak wood pellets, the resources were depleted and disturbed mostly due to lubricating oil, UF resin, Bio-binder, and saw dust, respectively, as shown in the Figure 8.

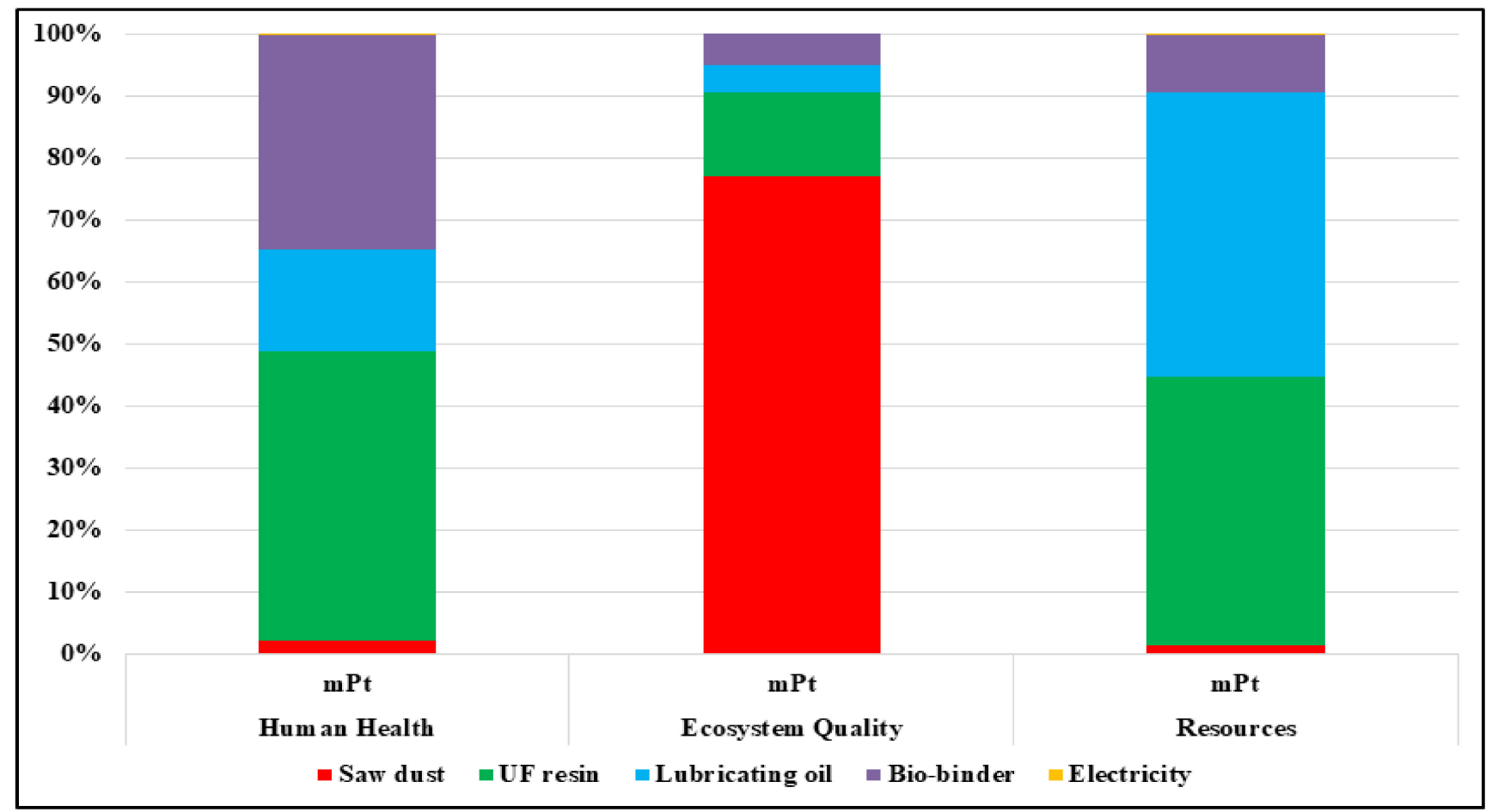

Figure 6. Single score damage assessment of wood pellets biofuel from Kikar tree species. 


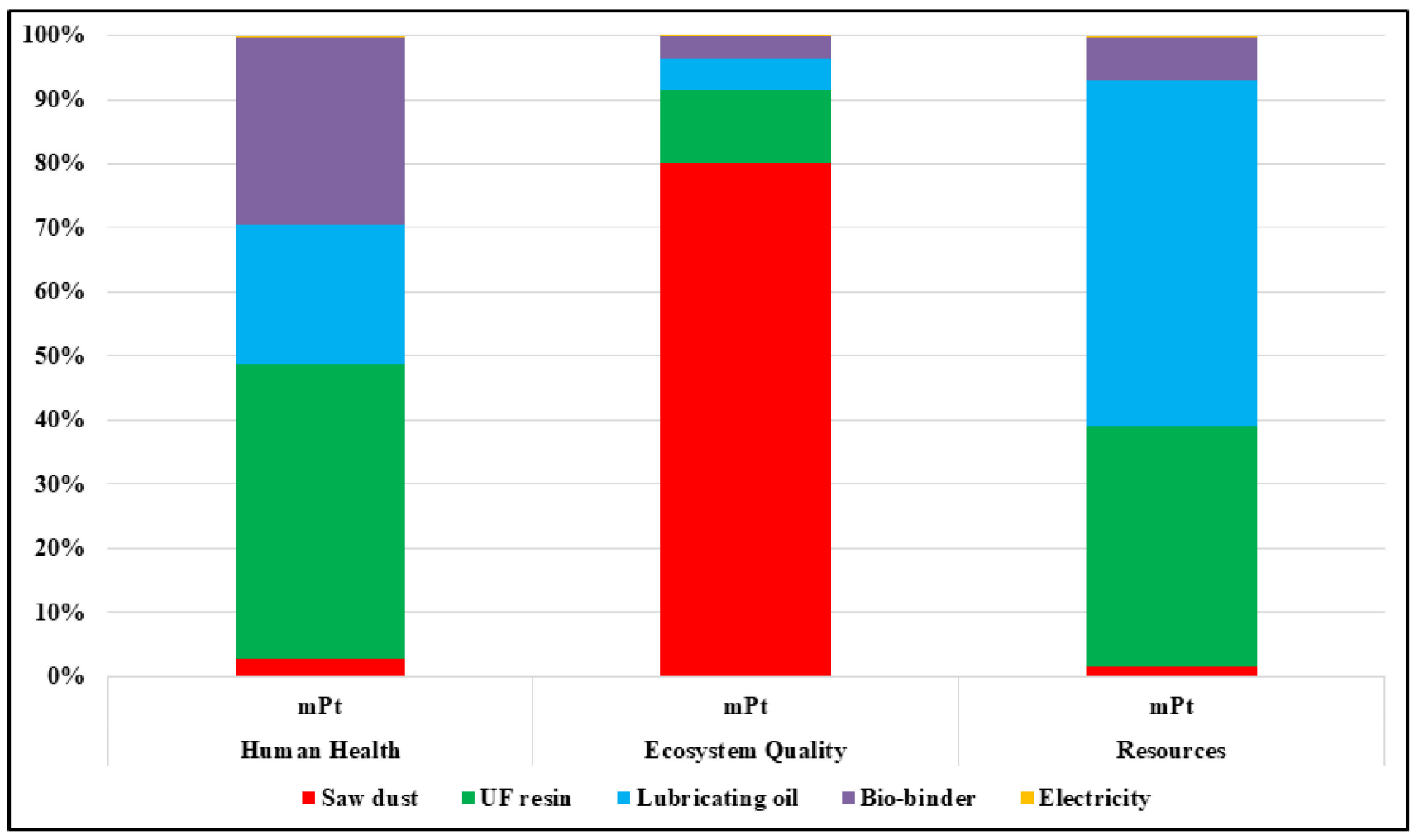

Figure 7. Single score damage assessment of wood pellets biofuel from Mesquite tree species.

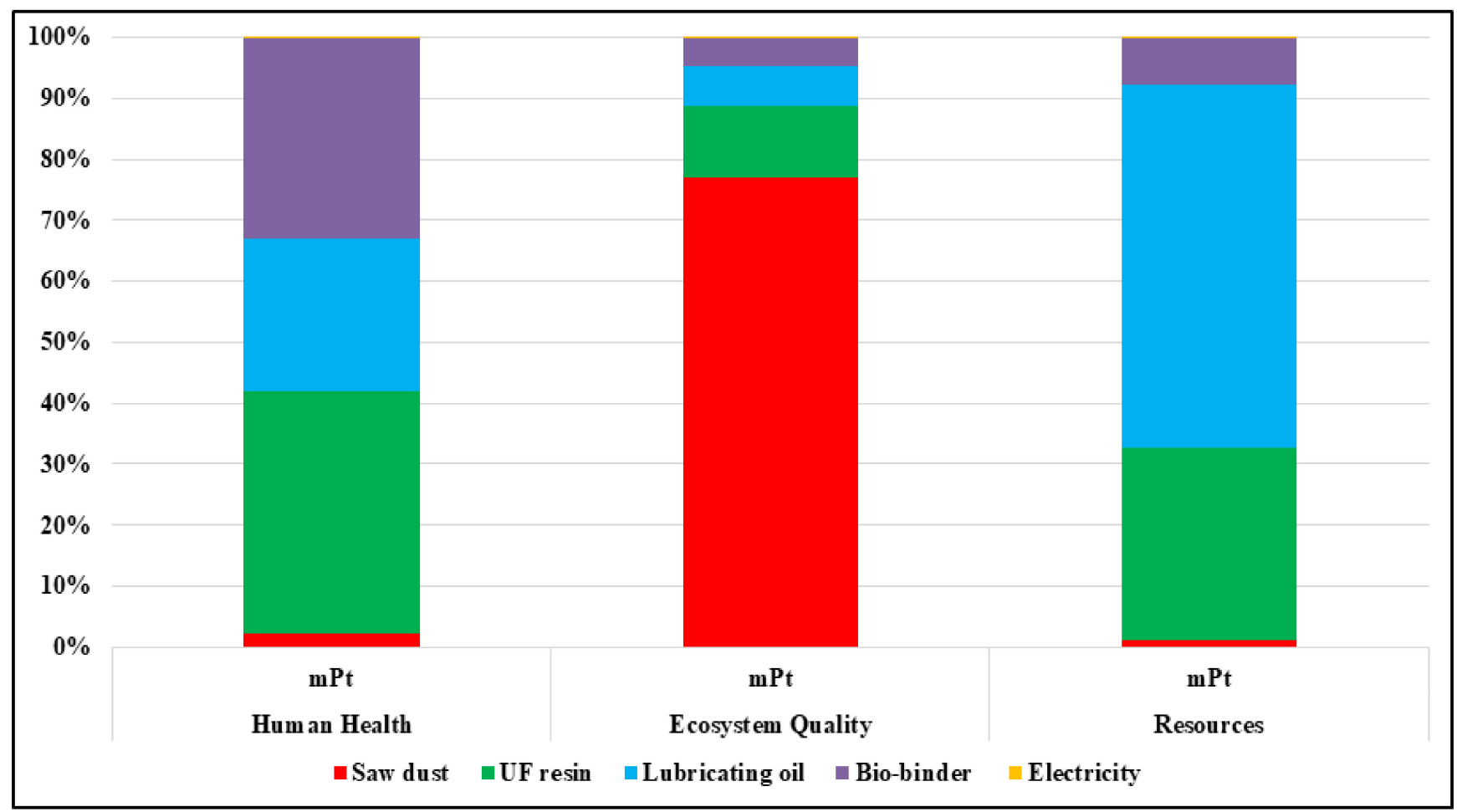

Figure 8. Single score damage assessment of wood pellets biofuel from Oak tree species.

\subsection{Cumulative Exergy Demand of Pellet Biofuel}

Cumulative exergy demand was calculated through SimaPro v.9.1 software with inbuilt methodology of Eco-indicator 99 (E) V2.10 for $1 \mathrm{~kg}$ wood pellets for three different tree species. In cumulative exergy, the highest impact was from Kikar saw dust wood pellets 
(37.19 MJ), followed by Oak wood pellets (31.99 MJ) and Mesquite wood pellets (29.41 MJ), while the highest exergy was for non-renewable, fossil from wood pellets obtained from the saw dust of Kikar, followed by Oak, and the lowest value was for Mesquite with the values of 23.93, 21.99, and 19.51 MJ, respectively. Renewable biomass and exergy were highest for wood pellets obtained from Kikar (10.859 MJ) saw dust, proceeded by Oak (8.226 MJ) and Mesquite (8.202 MJ), respectively, as shown in Figure 9. Exergy for renewable water was highest in Kikar wood pellets, followed by Mesquite and Oak wood pellets, respectively, with values of (0.94), (0.62) and (0.59 MJ), respectively.

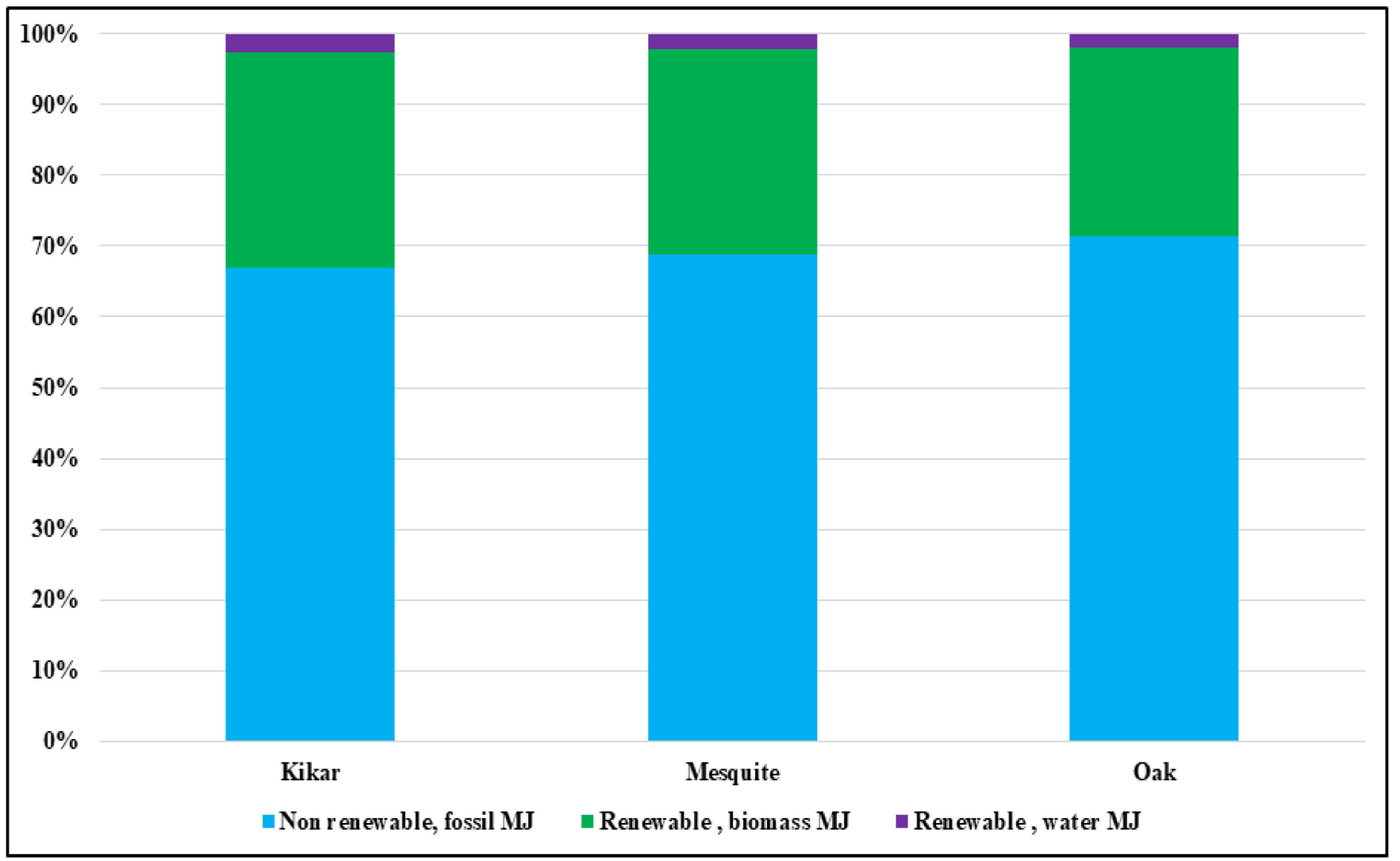

Figure 9. Cumulative exergy demand of wood pellets biofuel from different tree species.

\subsection{Single Score Exergy}

Single score exergy was calculated for $1 \mathrm{~kg}$ wood pellets biofuel through sima-pro v9.1 software Eco-indicator 99 (E) V2.10 baseline methodology. The highest non-renewable fossil exergy for Kikar wood pellets was from lubricating oil (11.351 MJ) followed by UF resin (9.989), bio-binder (2.20), and saw dust (0.341 MJ), respectively (Figure 10). Nonrenewable fossil exergy from Mesquite wood pellets was highest for lubricating oil, UF resin, bio-binder, and saw dust, with values of 10.784, 7.04, 1.33, and $0.30 \mathrm{MJ}$, respectively (Figure 11). The exergy of wood pellets (Oak saw dust) for non-renewable fossil was highest due to lubricating oil, followed by UF resin, bio-binder, and saw dust, as shown in the Figure 12. Renewable biomass exergy, when observed in Kikar wood pellets, was highest in saw dust (5.83 MJ), proceeded by bio-binder (4.856) and UF resin (0.131 MJ). Similarly, renewable biomass, when observed in Mesquite wood pellets, showed that saw dust was the highest contributor, followed by bio-binder and UF resin, as shown in the Figure 11. Saw dust, bio-binder and UF resin were the top contributors to renewable biomass with values of 4.52, 3.56 and $0.08 \mathrm{MJ}$, respectively, in wood pellets produced from Oak saw dust as shown in the Figure 12. UF resin and bio-binder were the top contributors to renewable water in wood pellets from Kikar tree species. The other factors-saw dust, lubricating oil, and electricity-showed minor values. In wood pellets from Mesquite saw 
dust, impacts on renewable water were mostly due to saw dust $(0.577 \mathrm{MJ})$ and bio-binder $(0.115 \mathrm{MJ})$, as shown in Figure 11. In Oak saw dust, bio-binder and electricity were the main factors in renewable water. Saw dust and lubricating oil showed minor/negligible values in renewable water.

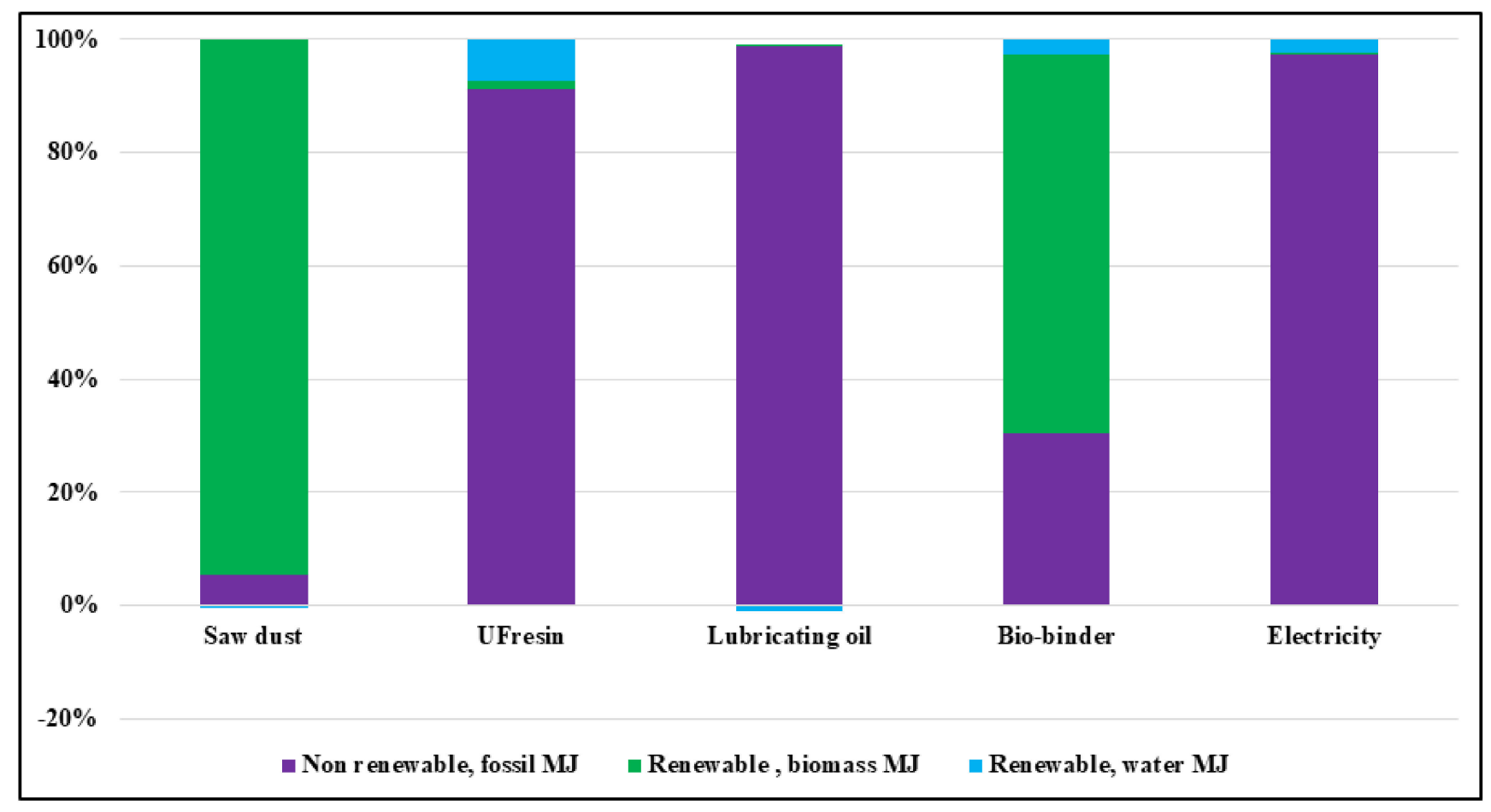

Figure 10. Single score exergy of wood pellets biofuel from Kikar tree species.

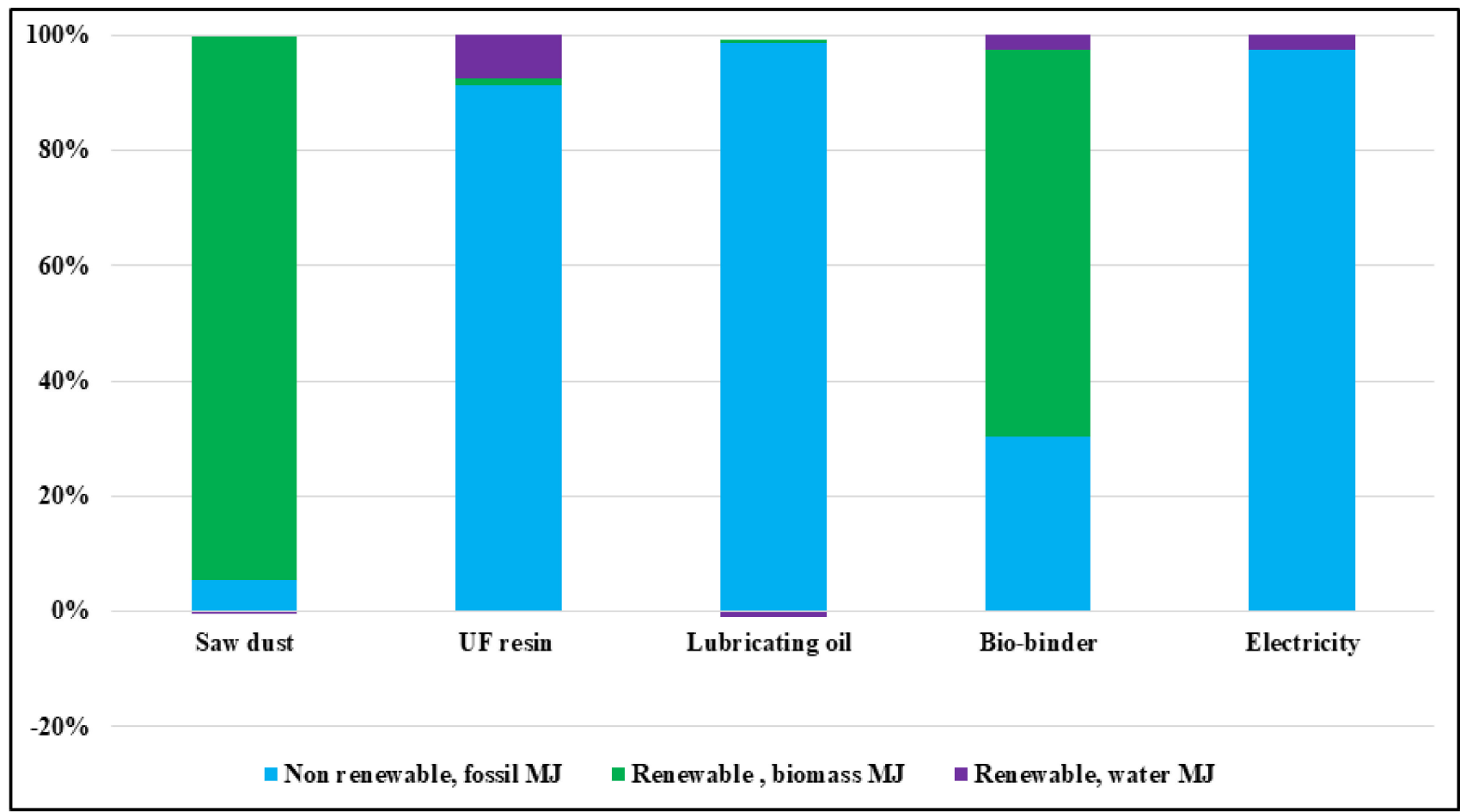

Figure 11. Single score exergy of wood pellets biofuel from Mesquite tree species. 


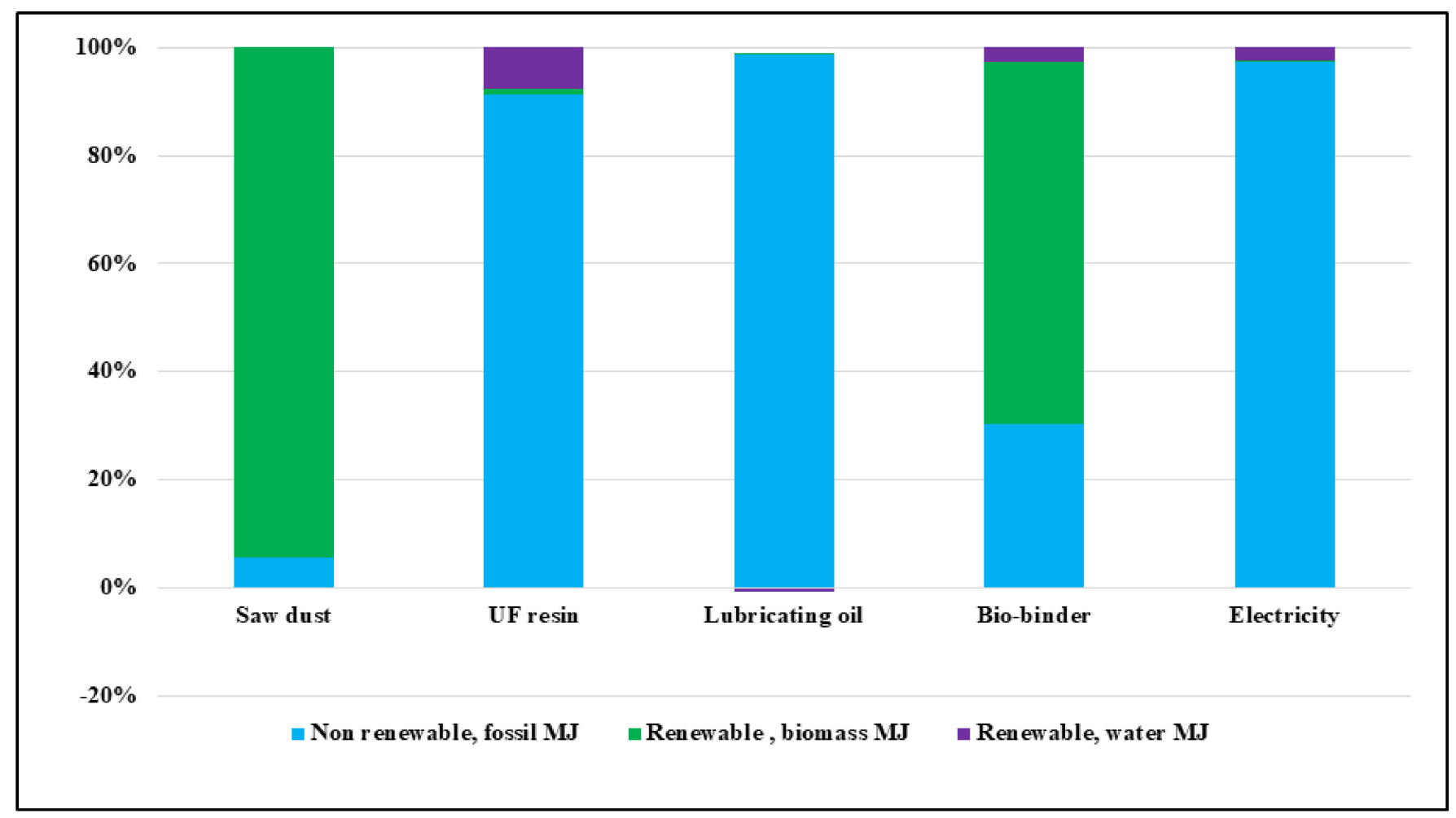

Figure 12. Single score exergy of wood pellets biofuel from Oak tree species.

\subsection{Wood Pellets Biofuel Characterization}

In this study, wood pellets were produced from saw dust, which was obtained from carpenters' shops and sawmills. Physical characterization of wood pellets was done in Laboratories of the Pakistan Forest Institute Peshawar and Department of Forestry and Wildlife Management, University of Haripur, Pakistan. Table 2 shows the characterization of wood pellets obtained from the saw dust of three different species of southern Khyber Pakhtunkhwa, whereas Table 3 exhibits the statistical analysis of wood pellets biofuel parameters having mean value, standard error, standard deviation, and variance for all the three tree species.

Table 2. Characterization of wood pellets Biofuel from different tree species.

\begin{tabular}{ccccc}
\hline Characterization & Unit & Mesquite Tree & Kikar Tree & Oak Tree \\
\hline Diameter & $\mathrm{mm}$ & 8.17 & 8.17 & 8.17 \\
Length & $\mathrm{mm}$ & 29.3 & 31.16 & 47.71 \\
Moisture content $(\mathrm{MC})$ & $\mathrm{wb} / \%$ & 8.8 & 7.9 & 7.8 \\
Ash content & $\%$ & 0.62 & 0.39 & 0.32 \\
Bulk Density & $\mathrm{kg} / \mathrm{dm}^{3}$ & 590 & 560 & 360 \\
Nitrogen & $\%$ & 0.55 & 0.82 & 0.61 \\
Sulphur & $\%$ & 0.04 & 0.02 & 0.04 \\
High heating values $(\mathrm{HHV})$ & $\mathrm{MJ} / \mathrm{kg}$ & 21.87 & 23.10 & 21.14 \\
Low heating values (LHV) & $\mathrm{MJ} / \mathrm{kg}$ & 20.13 & 21.32 & 19.00 \\
\hline
\end{tabular}


Table 3. Statistical analysis of wood pellets biofuel parameters.

\begin{tabular}{cccccc}
\hline Name of Parameters & N & Mean & Standard Error & Standard Deviation & Variance \\
\hline Diameter & 3 & 0.817 & 0.000 & 0.000 & 0.000 \\
Length & 3 & 3.605 & 0.585 & 1.013 & 1.027 \\
Moisture content & 3 & 8.166 & 0.317 & 0.550 & 0.303 \\
Bulk density & 3 & 0.503 & 0.072 & 0.125 & 0.016 \\
Ash content & 3 & 0.443 & 0.090 & 0.156 & 0.025 \\
HHV & 3 & 22.036 & 0.571 & 0.990 & 0.981 \\
LHV & 3 & 20.150 & 0.669 & 1.160 & 1.346 \\
Nitrogen & 3 & 0.660 & 0.081 & 0.141 & 0.020 \\
sulphur & 3 & 0.033 & 0.006 & 0.011 & 0.000 \\
\hline
\end{tabular}

\subsubsection{Dimensions}

The diameter $(8.17 \mathrm{~mm})$ of wood pellets was same for all the three species due to ring die, as shown in Table 2. The holes in the ring possessed the same diameter in the ring due to diameter being uniform for all wood pellets. Wood pellets length was variable, as shown in the Table 2, in which the highest length was for Oak wood pellets with value of $47.71 \mathrm{~mm}$, proceeded by Kikar $(31.16 \mathrm{~mm})$ and Mesquite wood pellets $(29.3 \mathrm{~mm})$.

\subsubsection{Moisture Content}

Moisture content in the wood pellets was within the range mentioned in literature and in different standards, which was $12 \%$, while in some standards, it was mentioned to be about $15 \%$. The moisture content was determined for saw dust as well as for wood pellets. The moisture content of saw dust was $14 \%, 10 \%$, and $8.7 \%$ for Mesquite, Kikar, and Oak, respectively. During production of wood pellets, some water was also added to saw dust. After pellets production, moisture content was determined by weighing the wood pellets and after weighing, heating the wood pellets in an oven, as mentioned in ASTM D1762-84. After heating, weighing the wood pellets once again gave us final moisture of wood pellets from different species, which were $8.8 \%, 7.9 \%$, and $7.8 \%$ for Mesquite, Kikar, and Oak, as shown in the Table 2.

\subsubsection{Ash Content}

The ash content of Mesquite wood pellets was 0.62 , followed by Kikar with 0.39 . The lowest ash content 0.32 was for Oak wood pellets. The Italian standard CTI-R04/05, for wood pellets biofuel, recommended ash content $\leq 0.7 \%$. While in our study, the ash content was within the recommended range. The ash content, when expressed in percentage, was $6.79 \%$ for Mesquite wood pellets, lagged by Kikar $4.23 \%$ and Oak 3.47\%.

\subsubsection{Bulk Density}

The bulk density of our studied wood pellets was 590, 560, and $360 \mathrm{~kg} / \mathrm{m}^{3}$ for Mesquite, Kikar, and Oak, respectively. Compared to Italian recommended bulk density $620-720 \mathrm{~kg} / \mathrm{m}^{3}$, the bulk density of our wood pellets samples was very low. The Table 2 shows the relationship between bulk density and moisture content. The higher the moisture content, the higher the bulk density will be.

\subsubsection{Heating Values}

The highest heating value was for Kikar wood pellets $(23.1 \mathrm{MJ} / \mathrm{kg})$, proceeded by Mesquite and Oak wood pellets, with values of 21.87 and $21.14 \mathrm{MJ} / \mathrm{kg}$, respectively. The high heating value, as recommended by Italian standard CTI-R04/05, shows the value of $>16.91 \mathrm{MJ} / \mathrm{kg}$. This shows that our studied wood samples follow within the recommended range, as shown in the Table 2. The low heating value was highest for wood pellets produced from Kikar saw dust, lagged by Mesquite and Oak wood pellets with values of 21.32, 20.13 and 19.00 MJ/kg, respectively. Recommended low heating value was not present in Italian standard CTI-R04/05, as shown in the Table 2. 


\subsubsection{Nitrogen and Sulphur Content}

Recommended nitrogen and Sulphur percentage in Italian standard were $\leq 0.3$ and $\leq 0.5 \%$, respectively. Our analyzed wood pellets, produced from the saw dust of three different species, showed high nitrogen percentage (\%) of $0.55,0.82$, and 0.61 for Mesquite, Kikar, and Oak wood pellets, which were not within the recommended range. The Sulphur content within the Mesquite, Kikar, and Oak was 0.04, 0.02, and 0.04\%. Recommended Sulphur content in Italian standard was $\leq 0.05 \%$; when compared to our studied wood pellets, samples show our wood pellets were within the range for Sulphur content, as shown in the Table 2.

\subsection{Discussion}

In the study, the moisture content of wood pellets was 8.8, 7.9, and 8.8\% for Mesquite, Kikar, and Oak wood pellets, respectively. The moisture of wood pellets manufactured in Finland was 7-12\% [39]. The pellet had moisture content (MC) between 6.0 (E) and 7.8\% (D). According to the Swedish standard SS-187120, the MC of pellets should be less than $10 \%$ or less than $12 \%$, depending on which standard group it belongs to [40]. Moisture content (MC) decreases heating values of wood pellets [41]. Higher MC in the wastes results in higher durability and bulk densities [42]. Opposite relationship was observed amongst MC and dimensions of wood pellets in a study of around eight different species [43]. According to [42], no such differences were observed for diameter and length, and they were according to the norms. While in the present study, differences were observed in length $29.3,31.16$, and $47.71 \mathrm{~mm}$ and diameter $8.71 \mathrm{~mm}$ with moisture variation of $8.8,7.9$ and $7.8 \%$ for Mesquite, Kikar and Oak, respectively.

The ash content was found to be $0.5 \%$ for wood pellets manufactured in Finland [39]. Quality of the wood pellets could be further improved by reducing the ash content limit instead of changing other parameters [44]. In several studies, it was illustrated that ashes increases mineral nutrition, soil fertility, and forest productivity $[45,46]$, while in our study, the ash content was within the limit as mentioned in Italian standards. Concerning bulk density, most tests showed values higher than $600 \mathrm{~kg} / \mathrm{m}^{3}$, which was higher than the lower limit [42]. In one more study, in which the burning of four different types of wood pellets were analyzed, it was found out that the bulk densities exceeded the lower recommended values [47]. The bulk and energy density were directly related to one another. The species B. tuldoides had the highest and significant bulk density value $\left(0.35 \mathrm{~g} / \mathrm{cm}^{3}\right)$ [48]. The results obtained for bulk density in our study showed lower values than the lower limit when compared to different studies, as well as recommended Italian standard.

Higher heating values for white coir was $18.5 \pm 0.3 \mathrm{MJ} / \mathrm{kg}$ and for brown coir was $19.0 \pm 0.2 \mathrm{MJ} / \mathrm{kg}$. Slight increase was observed in the results of HHV during the coconut maturation process. This could be due to degradation of hemicellulose [47]. The HHV is directly linked to lignin content [14]. In a study on the quality of wheat straw pellets, when wood residue and other types of biomass were used as a binder, the higher calorific value (17.98-18.77 MJ $/ \mathrm{kg}$ ) increased significantly [49]. The pellets produced presented very low values, considering nitrogen and sulphur content $(0.32 \pm 0.01$ and $0.04 \pm 0.002 \%$, respectively). In other words, roughly $80 \%$ less than the upper limit of the criteria consulted. Hence, it is estimated that both sulphur and nitrogen oxide emission limits would be negligible [40]. Nitrogen and Sulphur contents were low in all the three types of wood pellets, as required by DIN 51731 (1996) [41]. Nitrogen (0.28\%) and sulphur $(0.02 \%)$ content for sugarcane bagasse pellets found in our work was in accordance with all international standards [50].

Our findings are consistent with previous research in that environmental burdens are mainly associated with the production of adhesives and the burning of fossil fuels [51]. Study evaluated the results that natural gas-generated heat has a higher effect $(6.74 \mathrm{mPt})$ than wood pellet heat $(3.19 \mathrm{mPt})$, primarily due to the loss of fossil resources [9]. In another study, it was concluded that the use of wood bioethanol, as a partial replacement for petrol, decreases the fuel's global warming impact [52]. The primary reason for initiating 
global warming potential in the life cycles of the production of wood pellets is fossil fuel consumption [53]. The results showed a strong resemblance to the impacts of climate change, suggesting that the combustion of fossil fuels in the production chains of the WP dominates GHG emissions [54].

More than $50 \%$ of the total Ecotoxicity Potential was given by the underlying electricity mix used to produce the pellets in each of the WP production scenarios, lagged by the ignition of biomass (more than $30 \%$ of total) for drying the wood pellets [55]. Literature shows that UF resin, transportation, and electricity had the largest contribution to ecotoxicity: $37.60 \%, 31.42 \%$, and $16.76 \%$, respectively [35]. The second highest environmental impact category was ecotoxicity caused by wood pellets in our study. The major sources of ecotoxicity were: UF resin, bio-binder, and lubricating oil.

The main causes of abiotic depletion (AD) were natural gas (36.87\%), UF resin (34.17\%), and electricity (14.91\%) [35]. On the other hand, in the Brazilian and Portuguese particleboard development processes, UF resin $(30 \%)$ and $\mathrm{HFO}(35 \%)$ were responsible for most of the impacts in the AD effect group [56,57]. The AD effects of the production of HFO are mainly related to the extraction of minerals, coal, crude oils, and other non-renewable resources needed for its manufacture [58]. The hotspot source for mineral depletion was Kikar wood pellets, while the leading factor was UF resin.

The burning of wood pellets is dominated by acidification and eutrophication, due to ammonia, nitrogen oxide, and other pollutants during pellet combustion [52]. The energy mix accounts for more than $60 \%$ of the total acidification potential for the wood pellet scenarios, while sawmilling operations account for an additional $20 \%$ of the total acidification potential. The transport of wood pellets in the roundwood is the next major contributing factor at $13 \%$ of the overall acidification capacity [55]. The greatest contribution to acidification was from energy, UF resin, and transport; $41.6 \%, 25.49 \%$, and $21.94 \%$, respectively [55]. Heavy fuel oil (HFO) and UF resin are an important hotspot in the acidification potential effect group of Brazilian particleboard production due to the production of sulphur, methanol, and urea [56,57]. UF resin, bio-binder, and lubricating oil were responsible for acidification potential in wood pellets produced from Kikar, Mesquite, and Oak saw dust.

The environmental impact on human health is much more significant than the impact on the quality of the ecosystem and resources [9]. The most damage affected resource depletion and human health [59]. In damage assessment, the leading factor for damage was from Kikar wood pellets $(190.68 \mathrm{mPt})$, lagged by Oak wood pellets $(157.19 \mathrm{mPt})$ and Mesquite wood pellets $(146.22 \mathrm{mPt})$. The highest damage was posed to resources depletion with the contribution of ( $5.35 \mathrm{MJ}$ surplus), followed by ecosystem quality and human health with values of $\left(0.927\right.$ PAF.m $\left.{ }^{2} \mathrm{yr}\right)$ and $\left(5.35 \times 10^{-6} \mathrm{DALY}\right)$.

Among the cumulative exergy impact categories, the highest contribution was made by non-renewable fossil sources $(80 \%)$, while the combustion of renewable biomass in dryers was identified as the second largest contributor $(9 \%)$, followed by renewable water (3\%), among the different manufacturing processes, the production of UF resins, the consumption of fossil fuels, transportation, and elective activities [32], which is in accordance with other studies [35]. In cumulative exergy demand, the highest impact was from Kikar saw dust wood pellets (37.19 MJ), followed by Oak wood pellets (31.99 MJ) and Mesquite wood pellets $(29.41 \mathrm{MJ})$. Among the production process, the highest exergy was obtained for non-renewable, fossil for wood pellets obtained from the saw dust of Kikar, followed by Oak, and the lowest value obtained was for Mesquite, with the values of 23.93, 21.99, and $19.51 \mathrm{MJ}$, respectively. Renewable biomass and exergy attained was highest for wood pellets obtained from Kikar (10.859 MJ) saw dust, proceeded by Oak (8.226 MJ) and Mesquite (8.202 MJ), respectively. Exergy obtained from renewable water was highest in Kikar wood pellets, followed by Mesquite and Oak wood pellets, respectively, with values of $(0.94 \mathrm{MJ})$, $(0.62 \mathrm{MJ})$, and $(0.59 \mathrm{MJ})$, respectively. 


\subsection{Sensitivity Analysis for Wood Pellets}

Sensitivity analysis determines how different values of an independent variable affect a particular dependent variable under a given set of assumptions [60]. Sensitivity analysis focused on lubricating oil and UF resin to find impacts caused due to the above hotspot source. Table 4 showed the comparative environmental impacts from base line study with data in which $20 \%$ reduction in lubricating oil and UF resin, while in second case $0 \%$ of usage of UF resin, were observed. Table 5 showed the reduction in fossil fuel depletion, ecotoxicity, mineral depletion, and acidification/eutrophication potential. When $20 \%$ reduction was carried out in lubricating oil, similarly, 19\% reduction was observed in fossil fuels, $20 \%$ in ecotoxicity, $20 \%$ in mineral depletion, and $21 \%$ in acidification/eutrophication. Furthermore, when $20 \%$ reduction in UF resin was done and $16 \%$ reduction was observed in fossil fuel, $27.25,26.73$, and $25 \%$ reduction were observed in ecotoxicity, mineral depletion and acidification/eutrophication, respectively. In case 3, when no UF resin was used, a huge decrease was observed in environmental impacts with values of $42.67,66,63.37$, and $51.67 \%$ for fossil fuel, ecotoxicity, mineral depletion, and acidification or eutrophication potential, respectively. The comparative damage assessment to human health, ecosystem quality, and resources form the baseline results, with $20 \%$ reduction in lubricating oil, $20 \%$ UF resin, and without usage of UF resin, which had been shown in Table 5. A 20\% reduction in lubricating oil brought 20.47, 13.32, and 19\% decreases in human health, ecosystem quality, and resources, respectively. In case 2, 20\% reduction in UF resin carried out reduction in human health, ecosystem quality, and resources by 24,15 , and $16 \%$, respectively. Similarly, in case 3 , when $0 \%$ of UF resin was used for wood pellets production, $53 \%$ decrease was observed in human health, $2 \%$ in ecosystem quality, and $43.19 \%$ in resources.

Table 6 showed the scenario analysis of wood pellets for exergy, in which $20 \%$ reduction in lubricating oil caused 19\% reduction in non-renewable fossil, $16 \%$ in renewable biomass, and $21 \%$ in renewable water. Similarly, $20 \%$ decrease in UF resin caused $15 \%$ decrease in non-renewable fossil, $16 \%$ in renewable biomass, and $37 \%$ decrease in renewable water. Furthermore, without usage of UF, resin caused $42 \%$ decrease in non-renewable fossil, $2.5 \%$ reduction in renewable biomass, and $92 \%$ decrease in renewable water.

Table 4. Scenario analysis for environmental footprint of wood pellets biofuel, with $20 \%$ reduction in lubricating oil and Urea Formaldehyde (UF) resin.

\begin{tabular}{|c|c|c|c|c|}
\hline Impact Category & Fossil Fuel Depletion & Ecotoxicity & Mineral Depletion & $\overline{\text { Acidification/Eutrophication }}$ \\
\hline Unit & MJ Surplus & PAF.m $^{2} \mathrm{yr}$ & MJ Surplus & PDF.m² ${ }^{2} \mathrm{rr}$ \\
\hline Baseline value of lubricating oil & 1.8752 & 0.4801 & 0.0464 & 0.0300 \\
\hline $20 \%$ reduction in lubricating oil & 1.5222 & 0.3824 & 0.0369 & 0.0238 \\
\hline $\begin{array}{l}\text { Percent decrease in } \\
\text { environmental impacts }\end{array}$ & $19 \%$ & $20 \%$ & $20 \%$ & $21 \%$ \\
\hline \multicolumn{5}{|c|}{ Comparative environmental impacts assessment of wood pellets from baseline results with $20 \%$ reduction in UF resin } \\
\hline Baseline value of UF resin & 1.8752 & 0.4801 & 0.0464 & 0.0300 \\
\hline $20 \%$ reduction in UF resin & 1.5782 & 0.3493 & 0.0340 & 0.0225 \\
\hline $\begin{array}{l}\text { Percent decrease in } \\
\text { environmental impacts }\end{array}$ & $16 \%$ & $27 \%$ & $27 \%$ & $25 \%$ \\
\hline \multicolumn{5}{|c|}{ Comparative environmental impacts assessment of wood pellets from baseline results with $0 \%$ of UF resin } \\
\hline Baseline Value & 1.8752 & 0.4801 & 0.0464 & 0.0300 \\
\hline $0 \%$ of UF resin & 1.0751 & 0.1629 & 0.0170 & 0.0145 \\
\hline $\begin{array}{l}\text { Percent decrease in } \\
\text { environmental impacts }\end{array}$ & $42 \%$ & $66 \%$ & $63 \%$ & $52 \%$ \\
\hline
\end{tabular}


Table 5. Scenario analysis for damage assessment of wood pellets biofuel, with $20 \%$ reduction in lubricating oil and UF resin.

\begin{tabular}{|c|c|c|c|}
\hline Impact category & Human Health & Ecosystem Quality & Resource Depletion \\
\hline Unit & DALY & PAF.m ${ }^{2} \mathrm{yr}$ & MJ Surplus \\
\hline Baseline Value & $2.15 \times 10^{-6}$ & 0.353 & 1.922 \\
\hline $20 \%$ reduction in lubricating oil & $1.71 \times 10^{-6}$ & 0.306 & 1.559 \\
\hline Percent decrease in environmental impacts & $20 \%$ & $13 \%$ & $19 \%$ \\
\hline \multicolumn{4}{|c|}{ Comparative damage assessment of wood pellets from baseline data with $20 \%$ reduction in UF resin } \\
\hline Baseline Value & $2.15 \times 10^{-6}$ & 0.353 & 1.922 \\
\hline $20 \%$ reduction in UF resin & $1.63 \times 10^{-6}$ & 0.301 & 1.612 \\
\hline Percent decrease in environmental impacts & $24 \%$ & $15 \%$ & $16 \%$ \\
\hline \multicolumn{4}{|c|}{ Comparative damage assessment of wood pellets from baseline data with $0 \%$ of UF resin } \\
\hline Baseline Value & $2.15 \times 10^{-6}$ & 0.353 & 1.922 \\
\hline $0 \%$ of UF resin & $1.01 \times 10^{-6}$ & 0.346 & 1.092 \\
\hline Percent decrease in environmental impacts & $53 \%$ & $2 \%$ & $43 \%$ \\
\hline
\end{tabular}

Table 6. Scenario analysis for exergy of wood pellets biofuel with $20 \%$ reduction in lubricating oil.

\begin{tabular}{|c|c|c|c|}
\hline Impact Category & Non Renewable, Fossil & Renewable, Biomass & Renewable, Water \\
\hline Unit & MJ & MJ & MJ \\
\hline Baseline Value & 23.925 & 10.859 & 0.935 \\
\hline $20 \%$ reduction in lubricating oil & 19.430 & 9.086 & 0.735 \\
\hline Percent decrease in environmental impacts & $18.79 \%$ & $16.33 \%$ & $21.40 \%$ \\
\hline \multicolumn{4}{|c|}{ Comparative exergy of wood pellets from baseline data with $20 \%$ reduction in UF resin } \\
\hline Baseline Value & 23.925 & 10.859 & 0.935 \\
\hline $20 \%$ reduction in UF resin & 20.227 & 9.074 & 0.587 \\
\hline Percent decrease in environmental impacts & $15.46 \%$ & $16.44 \%$ & $37 \%$ \\
\hline \multicolumn{4}{|c|}{ Comparative exergy of wood pellets from baseline data with $0 \%$ of UF resin } \\
\hline Baseline Value & 23.925 & 10.859 & 0.935 \\
\hline Without useage of UF resin & 13.993 & 10.597 & 0.070 \\
\hline Percent decrease in environmental impacts & $41.50 \%$ & $2.40 \%$ & $92.50 \%$ \\
\hline
\end{tabular}

\section{Conclusions and Recommendations}

In the present study, low-emitting wood pellets biofuel was produced from sawdust of selected agro-forest tree species, i.e., Kikar (Acacia nilotica), Oak (Quercus semicarpifolia), and Mesquite (Prosopis juliflora) grown in the southern part of the Khyber Pakhtunkhwa (KP) province of Pakistan using indigenously developed technology (pelletizer machine). Life cycle inventory (LCI) was conducted for the entire production chain of the wood pellets biofuel by measuring quantities of various inputs (such as sawdust, bio-binder, specialty oil for pelletizer machine) consumed and output (wood pellets) produced. In addition, the wood pellets were characterized to examine diameter, length, moisture content, ash content, bulk density, high heating value (HHV), low heating value (LHV), as well as nitrogen and sulphur contents. The results of the present study were in accordance with the recommended Italian standard CTI-R 04/5, except for pellet bulk density and nitrogen content. The bulk density for all wood pellets, manufactured from the sawdust of three different agro-forest tree species, were lower than the recommended Italian standard, while for nitrogen content, the results were higher than the recommended Italian standard. Among the environmental impacts, Kikar (Acacia nilotica) wood pellets were the major contributor to fossil fuel depletion, followed by ecotoxicity, mineral depletion, and acidification/eutrophication. This was primarily due to lubricating/specialty oil and urea-formaldehyde (UF) resin used as inputs in the wood pellets biofuel manufacture. Likewise, human health and ecosystem quality was also affected by lubricating oil, UF resin, and saw dust, respectively. In cumulative exergy demand of $1 \mathrm{~kg}$ wood pellets 
biofuel, the highest impact was from Kikar wood pellets for non-renewable fossils, mainly due to lubricating oil used. Difference in environmental impacts, damage assessment and exergy were examined in three different scenarios for major hotspot inputs by reducing $20 \%$ lubricating oil in case 1,20\% UF resin in case 2 and without usage of UF resin in case 3, marked reduction was observed in ecotoxicity, fossil fuel, and mineral depletion, as well as acidification/eutrophication impact category. Moreover, a pronounced reduction was also noted in the non-renewable fossil fuel category of cumulative exergy demand of $1 \mathrm{~kg}$ of wood pellets biofuel produced. It is recommended that Government of Pakistan should install large-scale wood pellets mills for the mass production of pellets biofuel to increase energy contents and improve combustion properties of pellets, consumed for heating and cooking purposes, in households across the country. This study will also provide a base for the establishment of wood pellet industry in Pakistan, which will create employment opportunities and uplift the economic condition while transforming the petro-economy to bioeconomy in Pakistan.

Author Contributions: Conceptualization, M.H., T.K. and N.K.; methodology, A.R. and M.Z.H.; software, M.H., A.R. and M.Z.H.; validation, R.H.; formal analysis, A.R. and M.H.; investigation, S.G.N., F.I. and B.J.; resources, R.H.; data curation, I.U.M., N.K., F.I. and T.K.; writing-original draft preparation, A.R. and I.U.M.; writing-review and editing, R.H., S.G.N., N.K., F.I., M.Z.H., T.K., B.J. and M.H.; visualization, I.U.M., S.G.N., F.I. and B.J.; supervision, M.H.; project administration, M.H.; funding acquisition, M.H. All authors have read and agreed to the published version of the manuscript.

Funding: This research was funded by Higher Education Commission Islamabad under TTSF-HEC15 And the APC was funded by Charles Darwin University, Australia.

Institutional Review Board Statement: Not applicable.

Informed Consent Statement: Informed consent was obtained from all subjects involved in the study.

Data Availability Statement: Not applicable.

Acknowledgments: The authors are very thankful to Higher Education Commission (Islamabad Pakistan) for providing financial support to conduct this study under the project "Technology Transfer Support Fund" (TTSF)-HEC \#15.

Conflicts of Interest: There is no conflict of interest among the authors to publish this article.

Ethical Statement: The reported research work did not include any human based experimentation and questionnaires were filled with description of the research work and prior verbal consent was taken every respondent of this study, therefore no bioethical approval was required from Bioethics Committee of the University of Haripur, Pakistan to conduct this study.

\section{References}

1. Andreev, K.; Kantorová, V.; Bongaarts, J. Demographic Components of Futurepopulation Growth; Technical Paper No. 2013/3; United Nations Department of Economic and Social Affairs: New York, NY, USA, 2013.

2. Heinimö, J.; Junginger, M. Production and trading of biomass for energy-an overview of the global status. Biomass Bioenergy 2009, 33, 1310-1320. [CrossRef]

3. Orkustofnun, G. 2's United Nations. Geothermal Training in Iceland: Reports of the United Nations University Geothermal Training Programme in 2009, 12179. Available online: https://sustainabledevelopment.un.org/content/documents/3337energy_ georgsson.pdf (accessed on 17 August 2021).

4. Martins, F.; Felgueiras, C.; Smitkova, M.; Caetano, N. Analysis of fossil fuel energy consumption and environmental impacts in European countries. Energies 2019, 12, 964. [CrossRef]

5. Artemio, C.P.; Maginot, N.H.; Serafín, C.U.; Rahim, F.; Guadalupe, R.Q.J.; Fermín, C.M.; García, R. Characterization of Spanish biomass wastes for energy use. Bioresour. Technol. 2012, 103, 249-258.

6. El Bassam, N.; Maegaard, P. Integrated Renewable Energy for Rural Communities: Planning Guidelines, Technologies and Applications; Elsevier: Amsterdam, The Netherlands, 2004.

7. De Almeida, R.S.; Klotzle, M.C.; Pinto, A.C.F. Composição do conselho de Administração no setor de energia elétrica do Brasil. Rev. Adm. UNIMEP 2013, 11, 156-180. [CrossRef]

8. Fantozzi, F.; Buratti, C. Life cycle assessment of biomass chains: Wood pellet from short rotation coppice using data measured on a real plant. Biomass Bioenergy 2010, 34, 1796-1804. [CrossRef] 
9. Gil, M.V.; Casal, D.; Pevida, C.; Pis, J.J.; Rubiera, F. Thermal behaviour and kinetics of coal/biomass blends during co-combustion. Bioresour. Technol. 2010, 101, 5601-5608. [CrossRef]

10. Munir, S.; Daood, S.S.; Nimmo, W.; Cunliffe, A.M.; Gibbs, B.M. Thermal analysis and devolatilization kinetics of cotton stalk, sugar cane bagasse and shea meal under nitrogen and air atmospheres. Bioresour. Technol. 2009, 100, 1413-1418. [CrossRef] [PubMed]

11. Li, Z.; Zhao, W.; Li, R.; Wang, Z.; Li, Y.; Zhao, G. Combustion characteristics and NO formation for biomass blends in a 35-ton-per-hour travelling grate utility boiler. Bioresour. Technol. 2009, 100, 2278-2283. [CrossRef] [PubMed]

12. Qian, F.P.; Chyang, C.S.; Huang, K.S.; Tso, J. Combustion and NO emission of high nitrogen content biomass in a pilot-scale vortexing fluidized bed combustor. Bioresour. Technol. 2011, 102, 1892-1898. [CrossRef] [PubMed]

13. Demirbas, A. Importance of biomass energy sources for Turkey. Energy Policy 2008, 36, 834-842. [CrossRef]

14. Bahng, M.K.; Mukarakate, C.; Robichaud, D.J.; Nimlos, M.R. Current technologies for analysis of biomass thermochemical processing: A review. Anal. Chim. Acta 2009, 651, 117-138. [CrossRef] [PubMed]

15. FAO. 2017. Available online: http://www.fao.org/faostat/en/\#data (accessed on 7 January 2018).

16. Purohit, P.; Chaturvedi, V. Biomass pellets for power generation in India: A techno-economic evaluation. Environ. Sci. Pollut. Res. 2018, 25, 29614-29632. [CrossRef] [PubMed]

17. WBA. Pellets a Fast-Growing Energy Carrier; World Bioenergy Association: Stockholm, Sweden, 2014.

18. Dwivedi, P.; Khanna, M.; Bailis, R.; Ghilardi, A. Potential greenhouse gas benefits of transatlantic wood pellet trade. Environ. Res. Lett. 2014, 9, 024007. [CrossRef]

19. Sikkema, R.; Steiner, M.; Junginger, M.; Hiegl, W.; Hansen, M.T.; Faaij, A. The European wood pellet markets: Current status and prospects for 2020. Biofuels Bioprod. Biorefining 2011, 5, 250-278. [CrossRef]

20. Hanssen, S.V.; Duden, A.S.; Junginger, M.; Dale, V.H.; van der Hilst, F. Wood pellets, what else? Greenhouse gas parity times of European electricity from wood pellets produced in the south-eastern United States using different softwood feedstocks. Gcb Bioenergy 2017, 9, 1406-1422. [CrossRef]

21. Prestemon, J.P.; Wear, D.N.; Foster, M.O. The Global Position of the US Forest Products Industry; e-Gen. Technical Report SRS-204; US Department of Agriculture Forest Service, Southern Research Station: Asheville, NC, USA, 2015; Volume 204, 24p.

22. Hoefnagels, R.; Junginger, M.; Faaij, A. The economic potential of wood pellet production from alternative, low-value wood sources in the southeast of the US. Biomass Bioenergy 2014, 71, 443-454. [CrossRef]

23. Abt, K.L.; Abt, R.C.; Galik, C.S.; Skog, K.E. Effects of Policies on Pellet Production and Forests in the US South: A Technical Document Supporting the Forest Serviceupdate of the 2010 RPA Assessment; US Department of Agriculture Forest Service, Southern Research Station: Asheville, NC, USA, 2014; Volume 202, 33p.

24. Fantozzi, F.; Barbanera, M.; Buratti, C. Life cycle analysis of wood pellet from SRC through direct measuring of energy consumption. In Proceeding of 14th European Biomass Conference and Exibition, Biomass for Energy, Industry and Climate Protection, Paris, France, 17-21 October 2005.

25. Maraver, G.; Carpio, M.; Factors Affecting Pellet Quality. WIT Transactions on State of the Art in Science and Engineering; WIT Press: Southampton, UK, 2022; Volume 85. [CrossRef]

26. Ullah, M.; Mehmood, S.; Ali, M.; Bussmann, R.W.; Aldosari, A.; Khan, R.A.; Ullah, R.; Hussain, W.; Shah, M.A.R. An ethnopharmacological study of plants used for treatment of diabetes in the Southern and Tribal regions of Khyber Pakhtunkhwa province, Pakistan. Ethnobot. Res. Appl. 2019, 18,1-20. [CrossRef]

27. Bakhtullah, F.P.; Shahid, M.; Basit, A.; Khan, M.A.; Gul, S.; Wazir, I.; Raqeebullah, K.R. Sero-prevalence of brucellosis in cattle in southern area of Khyber Pakhtunkhwa, Pakistan. Res. J. Vet. Pract. 2014, 2, 63-66.

28. Khan, R. Facts about AZRI; Pakistan Agricultural Research Council, Arid Zone Research Institute Ratta Kulachi: DI Khan, Pakistan, 2003; pp. 2-4.

29. Ullah, M.; Khan, M.U.; Mahmood, A.; Malik, R.N.; Hussain, M.; Wazir, S.M.; Daud, M.; Shinwari, Z.K. An ethnobotanical survey of indigenous medicinal plants in Wana district south Waziristan agency, Pakistan. J. Ethnopharmacol. 2013, 150, 918-924. [CrossRef]

30. Hamid, A.; Mahmood, T.; Fatima, H.; Hennelly, L.M.; Akrim, F.; Hussain, A.; Waseem, M. Origin, ecology and human conflict of gray wolf (Canis lupus) in Suleman Range, South Waziristan, Pakistan. Mammalia 2019, 83, 539-551. [CrossRef]

31. Hussain, M.; Malik, R.N.; Taylor, A. Carbon footprint as an environmental sustainability indicator for the particleboard produced in Pakistan. Environ. Res. 2017, 155, 385-393. [CrossRef] [PubMed]

32. International Organization for Standardization. Environmental Management: Life Cycle Assessment; Principles and Framework; ISO: Geneva, Switzerland, 2006; Volume 14044.

33. Adams, P.; Shirley, J.; McManus, M. Comparative cradle-to-gate life cycle assessment of wood pellet production with torrefaction Appl. Energy 2015, 138, 367-380. [CrossRef]

34. Kouchaki-Penchah, H.; Sharifi, M.; Mousazadeh, H.; Zarea-Hosseinabadi, H. Life cycle assessment of medium-density fiberboard manufacturing process in Islamic Republic of Iran. J. Clean. Prod. 2016, 112, 351-358. [CrossRef]

35. Adams, P.; McManus, M. Small-scale biomass gasification CHP utilisation in industry: Energy and environmental evaluation. Sustain. Energy Technol. Assess. 2014, 6, 129-140. [CrossRef]

36. Testing of Solid Fuels, Compressed Untreated Wood. Requirements and Testing; DIN 51731; German Institute for Standardisation: Berlin, Germany, 1996. 
37. Nzihou, J.F.; Hamidou, S.; Bouda, M.; Koulidiati, J.; Segda, B.G. Using Dulong and Vandralek formulas to estimate the calorific heating value of a household waste model. Int. J. Sci. Eng. Res. 2014, 5, 1878-1883.

38. Alakangas, E. European Standard (EN 14961) for wood chips and hog fuel. For. Bioenergy 2010, 47, 329-340.

39. Sis, S. Biobränslen och Torv—Bränslepellets_Klassificering (Biofuels and Peat_Fuel Pellets—Classification); SS 187120; SIS Förlag AB: Stockholm, Sweden, 1998.

40. Gündüz, G.; Saraçoğlu, N.; Aydemir, D. Characterization and elemental analysis of wood pellets obtained from low-valued types of wood. Energy Sources Part A Recovery Util. Environ. Eff. 2016, 38, 2211-2216. [CrossRef]

41. Miranda, M.T.; Sepúlveda, F.J.; Arranz, J.I.; Montero, I.; Rojas, C.V. Analysis of pelletizing from corn cob waste. J. Environ. Manag. 2018, 228, 303-311. [CrossRef]

42. Poddar, S.; Kamruzzaman, M.; Sujan, S.M.A.; Hossain, M.; Jamal, M.S.; Gafur, M.A.; Khanam, M. Effect of compression pressure on lignocellulosic biomass pellet to improve fuel properties: Higher heating value. Fuel 2014, 131, 43-48. [CrossRef]

43. Toscano, G.; Duca, D.; Amato, A.; Pizzi, A. Emission from realistic utilization of wood pellet stove. Energy 2014, 68, 644-650. [CrossRef]

44. Maeda, S.; da Silva, H.D.; Cardoso, C. Resposta de Pinus taeda L. À aplicação de cinza de biomassa vegetal em Cambissolo Húmico, em vaso. Embrapa Florestas Artigo Periódico Indexado ALICE 2008, 56, 43-52.

45. Zhang, F.-S.; Yamasaki, S.; Nanzyo, M. Waste ashes for use in agricultural production: I. Liming effect, contents of plant nutrients and chemical characteristics of some metals. Sci. Total Environ. 2002, 284, 215-225. [CrossRef]

46. Arranz, J.I.; Miranda, M.T.; Montero, I.; Sepúlveda, F.J.; Rojas, C.V. Characterization and combustion behaviour of commercial and experimental wood pellets in South West Europe. Fuel 2015, 142, 199-207. [CrossRef]

47. Sette, C.R., Jr.; Freitas, P.D.C.; Freitas, V.P.; Yamaji, F.M.; Almeida, R.A. Production and characterization of bamboo pellets. Biosci. J. 2016, 32, 922-930. [CrossRef]

48. Lu, D.; Tabil, L.G.; Wang, D.; Wang, G.; Emami, S. Experimental trials to make wheat straw pellets with wood residue and binders. Biomass Bioenergy 2014, 69, 287-296. [CrossRef]

49. De Almeida, L.F.P.; Sola, A.V.H.; Behainne, J.J.R. Sugarcane bagasse pellets: Characterization and comparative analysis. Acta Scientiarum. Technol. 2017, 39, 461-468. [CrossRef]

50. Oneil, E.; Kline, E. Cradle to Gate Life Cycle Assessment of Oriented Strandboard Production from the Southeast. 2012. Available online: https:/ / citeseerx.ist.psu.edu/viewdoc/download?doi=10.1.1.432.4604\&rep=rep1\&type=pdf (accessed on 13 September 2021).

51. Sandilands, J.; Kellenberger, D.; Nicholas, I.; Nielsen, P. Life cycle assessment of wood pellets and bioethanol from wood residues and willow. NZJ For. Sci. 2009, 53, 25-33.

52. Chen, S. Life Cycle Assessment of Wood Pellet. Master's Thesis, Chalmers University of Technology, Göteborg, Sweden, 2009.

53. Park, C.; Jeong, B.; Zhou, P.; Jang, H.; Kim, S.; Jeon, H.; Nam, D.; Rashedi, A. Live-Life Cycle Assessment of the Electric Propulsion Ship using Solar PV. Appl. Energy 2022, 309, 118477. [CrossRef]

54. Morrison, B.; Golden, J.S. Life cycle assessment of co-firing coal and wood pellets in the Southeastern United States. J. Clean. Prod. 2017, 150, 188-196. [CrossRef]

55. Silva, D.A.L.; Mendes, N.C.; Varanda, L.D.; Ometto, A.R.; Lahr, F.A.R. Life cycle assessment of urea formaldehyde resin: Comparison by CML (2001), EDIP (1997) and USEtox (2008) methods for toxicological impact categories. In Re-Engineering Manufacturing for Sustainability; Springer: Berlin/Heidelberg, Germany, 2013; pp. 529-534.

56. Silva, D.A.L.; Ometto, A.R.; Garcia, R.P.; Freire, F.M.C.S.; Varanda, L.D.; Christoforo, A.L. Life Cycle assessment of wood-based composites: State-of-the-art and opportunities for reducing environmental impacts. In Non-Conventional Building Materials Based on Agro-Industrial Wastes; Tiliform: Bauru, Brasil, 2015; p. 143.

57. Garcia, R.; Freire, F. Environmental assessment of wood-based panels: A comparison of life-cycle-based tools. Int. J. Sustain. Constr. 2012, 1, 63-71.

58. Pergola, M.; Gialdini, A.; Celano, G.; Basile, M.; Caniani, D.; Cozzi, M.; Gentilesca, T.; Mancini, I.M.; Pastore, V.; Romano, S.; et al. An environmental and economic analysis of the wood-pellet chain: Two case studies in Southern Italy. Int. J. Life Cycle Assess. 2018, 23, 1675-1684. [CrossRef]

59. Saltelli, A.; Tarantola, S.; Campolongo, F.; Ratto, M. Sensitivity Analysis in Practice: A Guide to Assessing Scientific Models; Wiley Online Library: Hoboken, NJ, USA, 2004; Volume 1.

60. Khanam, T.; Khalid, F.; Manzoor, W.; Rashedi, A.; Ullah, F.; Rehman, F.; Hadi, R.; Akhtar, A.; Babu, K.; Hussain, M. Environmental sustainability assessment of biodiesel production from Jatropha curcus L. seeds oil in Pakistan. PLoS ONE 2021, 16, e0258409. [CrossRef] [PubMed] 